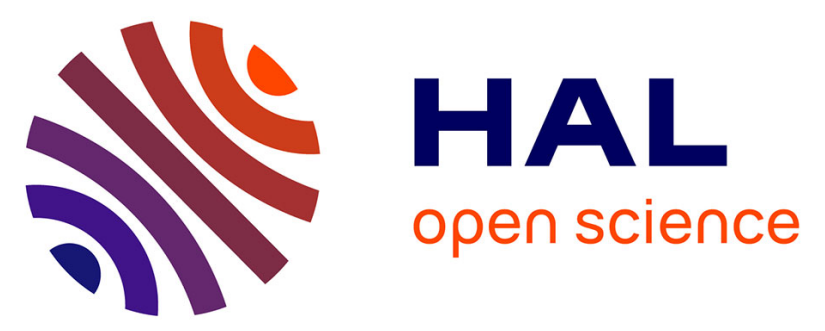

\title{
Assessment of the ecological and human health risks from metals in shrimp aquaculture environments in Central Java, Indonesia
}

Nuning Vita Hidayati, Pascale Prudent, Laurence Asia, Laurent Vassalo, Franck Torre, Ita Widowati, Agus Sabdono, Agung Dhamar Syakti, Pierre Doumenq

\section{To cite this version:}

Nuning Vita Hidayati, Pascale Prudent, Laurence Asia, Laurent Vassalo, Franck Torre, et al.. Assessment of the ecological and human health risks from metals in shrimp aquaculture environments in Central Java, Indonesia. Environmental Science and Pollution Research, 2020, 27 (33), pp.4166841687. 10.1007/s11356-020-09967-8 . hal-03059640

\section{HAL Id: hal-03059640 https://hal.science/hal-03059640}

Submitted on 1 Mar 2021

HAL is a multi-disciplinary open access archive for the deposit and dissemination of scientific research documents, whether they are published or not. The documents may come from teaching and research institutions in France or abroad, or from public or private research centers.
L'archive ouverte pluridisciplinaire HAL, est destinée au dépôt et à la diffusion de documents scientifiques de niveau recherche, publiés ou non, émanant des établissements d'enseignement et de recherche français ou étrangers, des laboratoires publics ou privés. 


\title{
Assessment of the ecological and human health risks from metals in shrimp aquaculture environments in Central Java, Indonesia
}

\author{
Nuning Vita Hidayati ${ }^{1,2,3,4}$ \& Pascale Prudent ${ }^{1}$ \& Laurence Asia ${ }^{1}$ \& Laurent Vassalo ${ }^{1}$ \& Franck Torre ${ }^{5}$ \& Ita Widowati ${ }^{3}$ \& \\ Agus Sabdono ${ }^{3}$ \& Agung Dhamar Syakti ${ }^{4,6}$ \& Pierre Doumenq ${ }^{1}$
}

\author{
Aix-Marseille University, CNRS, LCE, Marseille, France \\ Fisheries and Marine Science Faculty, Jenderal Soedirman University, Kampus Karangwangkal, Jl. dr. Suparno, Purwokerto 53123, Indonesia \\ Faculty of Fisheries and Marine Sciences, Diponegoro University, Jl. Prof. H. Soedharto, SH, Tembalang, Semarang 50275, Indonesia \\ Center for Maritime Biosciences Studies - Institute for Sciences and Community Service, Jenderal Soedirman University, Kampus Karangwangkal, Jl. dr. \\ Suparno, Purwokerto 53123, Indonesia \\ 5 Aix-Marseille University, CNRS, IMBE, IRD, Avignon Université, Marseille, France \\ 6 Marine Science and Fisheries Faculty, Raja Ali Haji Maritime University, Jl. Politeknik, Senggarang, Tanjungpinang, Riau Islands Province \\ 29100, Indonesia
}

\begin{abstract}
The occurrence and contamination level of seven important toxic metals $(\mathrm{Cd}, \mathrm{Cu}, \mathrm{Co}, \mathrm{Cr}, \mathrm{Hg}, \mathrm{Pb}$, and $\mathrm{Zn})$ and three additional metals ( $\mathrm{Al}, \mathrm{Fe}$, and $\mathrm{Mn}$ ) in the water, sediment, and shrimp muscle in aquaculture areas located in Central Java, Indonesia, were investigated. The results suggest that the majority of metals have higher concentrations in the inlet followed by the outlet and ponds. Cd dissolved in the waters exhibited the highest level in Pekalongan $\left(3.15 \pm 0.33 \mu \mathrm{g} \mathrm{L}^{-1}\right)$. Although Pb was not detected in the water, it was detected in the sediment, and the concentration ranged from 7.6 to $15.40 \mathrm{mg} \mathrm{kg}^{-1} \mathrm{dw}$. In general, the heavy metal concentrations in the sediments were found to decrease in the sequence $\mathrm{Al}>\mathrm{Fe}>\mathrm{Mn}>\mathrm{Zn}>\mathrm{Cr}>\mathrm{Cu}>\mathrm{Co}>\mathrm{Pb}$. Concentrations below the effects range low level based on the Canadian sediment quality guidelines were found for $\mathrm{Cr}, \mathrm{Cu}$, $\mathrm{Pb}$, and $\mathrm{Zn}$, whereas moderate sediment pollution (25-75 mg kg${ }^{-1} \mathrm{dw}$ ) was observed for $\mathrm{Cr}$ (all regions), $\mathrm{Cu}$ (except in the Pekalongan region), and Zn (Brebes and Tegal regions) according to the USEPA standard. The status of the waters was evaluated by calculating a pollution index derived mostly from $\mathrm{Mn}$ and $\mathrm{Zn}$. The ecological risk (geoaccumulation index $\left(I_{\text {geo }}\right)$, contamination factor (CF), pollution load index (PLI), and potential ecological risk index (ERI)) determined in the sediments indicated that all studied areas had low to moderate contamination. The concentrations of all metals in shrimp were generally below the maximum limits for seafood, except for $\mathrm{Zn}$ (in all stations), $\mathrm{Pb}$, and $\mathrm{Cr}$ (Tegal and Pekalongan). The hazard index values for metals indicated that consuming shrimp would not have adverse effects on human health.
\end{abstract}

Keywords Sustainable aquaculture $\cdot$ Litopenaeus vannamei $\cdot$ Food safety $\cdot$ Trace metals $\cdot$ Pollution index 


\section{Introduction}

World aquaculture production continues to increase, with shrimp farming representing one of the major aquaculture industries. The shrimp market has become the most valuable globally traded seafood commodity and had the highest production value in 2016. In the same year, FAO data classified Indonesia as the third largest aquaculture producer, with

production reaching 4,950,000 tons, which accounted for 6.18\% of the world's aquaculture production (FAO 2018a). In Indonesia, white-legged shrimp, also known as the king prawn (Litopenaeus vannamei), is the dominant farmed spe- cies, and it generates the highest revenue on a per $\mathrm{kg}$ basis compared to the other fishery commodities (KKP 2017).

The expansion and intensification of this sector have em- phasized the need for continuous monitoring and control of environmental quality, which is essential for ensuring the sus- tainability of aquaculture and the safety of the product (Paul and Vogl 2013) based on the 14th indicator of the Sustainable Development Goals Agenda 2030, which aimed to ensure the contribution and conduct of fisheries and aquaculture towards food security and nutrition (FAO 2018b). Good water quality is also essential in aquaculture to maintain the health, optimal growth, and survival of the cultured species (Mohanty et al. 2018; Suantika et al. 2018).

Shrimp aquaculture environments face natural and human impacts from urban and suburban areas. In this study, we focused on seven important toxic metals $(\mathrm{Cd}, \mathrm{Cu}, \mathrm{Co}, \mathrm{Cr}$, mercury $(\mathrm{Hg}), \mathrm{Pb}$, and $\mathrm{Zn}$ ) and three additional metals $(\mathrm{Al}, \mathrm{Fe}$, and $\mathrm{Mn})$ related to their transportation. These metals can enter aquatic environments through surface runoff and from natural sources, such as geologic weathering and atmospheric inputs, or they can be derived via effluent discharge from multiple anthropogenic sources, including industrial, agricul- tural (Gu et al. 2014), mining, shrimp farming (Lacerda et al. 2006), and domestic effluents (Ju et al. 2017; Sarkar et al. 2016).

Heavy metal contamination is becoming a major con- cern in coastal systems, which are often associated with shrimp farming activity (Syakti et al. 2015), due to the ability of heavy metals to persist in the environment (Ju et al. 2017). Heavy metals are also toxic at high concentra- tions (Sfakianakis et al. 2015) and could pose risks to hu- man health (Fakhri et al. 2018; Garcia-Hernandez et al. 2018; Zhang et al. 2018), which is why exposure must be evaluated.

In the present study, we monitored the occurrence and evaluated the state of contamination of ten metals $(\mathrm{Al}, \mathrm{Cd}, \mathrm{Co}, \mathrm{Cr}$, $\mathrm{Cu}, \mathrm{Fe}, \mathrm{Mn}, \mathrm{Pb}, \mathrm{Zn}, \mathrm{Hg}$ ) in three environmental ma- trices, i.e., water, sediment, and shrimp, from the aquaculture area in Indonesia, which is located on the northern coast of Central Java in the Brebes, Tegal, Pekalongan, and Pemalang regions. Some studies have reported that aquatic organisms tend to take metals up from their direct environment (Núñez- Nogueira et al. 2012; Wang et al. 2013). For water samples, we investigated the occurrence of metals in the environment and evaluated their contamination and/or status in order to determine whether the quality of the aquatic environment is suitable for intended uses, i.e., aquaculture. Our evaluation based on the extent of dissolved metals in water compared acceptable or safe metal levels via direct comparisons and appropriate indexes. Sediment is a primary location for metal accumulation in the environment and is the main source of contamination in the water column due to resuspension and trapping processes associated with salinity or metal dissolu- tion through biotic/abiotic processes. As a valuable commod- ity, shrimp muscle tissue must be monitored for contaminants, e.g., heavy metals, because these animals live in water and are in contact with sediments. Several studies have documented the ability of shrimp to accumulate these metals in their tissues since many metals have the ability to form complexes with organic substances (Jonathan et al. 2017; Nascimento et al. 2016; Pourang et al. 2004; Ruelas-Inzunza and Páez-Osuna 2004; Qiu 2015; Zhang et al. 2016). These metals do not tend to be excreted and thus may be passed up the food chain to higher organisms, including humans (Soto-Jiménez et al. 2011). Due to its high toxicity, we also evaluated the levels of $\mathrm{Hg}$ in the edible muscles of the shrimp. In this study, we investigated the occurrence of metals in the environment and the contamination status and assessed the potential ecological and human health risks.

\section{Materials and methods}

\section{Study area}

Sampling campaigns were carried out in shrimp farms in four major areas located on the north coast of Central Java, i.e., the Brebes, Tegal, Pekalongan, and Pemalang regions (Fig. 1). These different regions were selected as the target study areas since they are the highest producers of shrimp in Central Java, which is characterized by water sources from different riverine systems that are among the most important in Indonesia. In each selected area, twenty ponds were selected: 4 ponds in Brebes, 4 in Tegal, 5 in Pekalongan, and 7 in Pemalang. The sample number from each site was determined based on the number of shrimp ponds in each area. Brebes Regency is a shrimp farming center in Central Java that covers 14 ha of intensive shrimp farming and 403 ha of extensive shrimp farming. However, shrimp production in Brebes has de- creased since 2016 due to environmental pressures, 
such as industrial waste, agricultural fertilizers, onion/shallot farming activities, industrial activities, and settlements (Bayuaji et al. 2018). It is well documented that there are many problems associated with heavy metal contamination in this area (Ismanto 2019; Hartini 2011).

The shrimp farms in Tegal have a lowland topography with upstream rivers flowing into the Java Sea. Tegal has four rivers that pass through 16 villages (59.26\%). Similar to Brebes, L. vannamei shrimp farms have shown declining shrimp production, and the two largest threats to production are the spread of shrimp white feces disease (0.76) and envi- ronmental pollution $(0.67)$. Pemalang consists of a $363.82 \mathrm{~km}^{2}$ wetland area and a $751.48 \mathrm{~km}^{2}$ nonwetland area (BPS 2018c). The population of Pemalang Regency generally lives in coastal areas in city centers, and the number of people living in coastal areas accounts for $57.77 \%$ of the total population (Wahyuningrat et al. 2018). The area of farms in this region is 1728 ha and includes milkfish and shrimp farms. Moreover, the fisheries sector is the largest contributor to the gross re- gional domestic product in this regency (Wahyuningrat et al. 2018). In parallel with the contribution of the shrimp sector to the local economy of the region, there are many problems in local ecosystems caused by anthropogenic activity, including $\mathrm{Pb}$ and $\mathrm{Cd}$ contamination, which might originate from domes- tic waste in the upstream areas carried by the Comal River (Puspita et al. 2018; Yulianto et al. 2019) and deterioration of soil and water quality related to mangrove exploitation in this coastal region (Sawitri and Karlina 2006). Pekalongan has a coastline along the Java Sea of approximately $6 \mathrm{~km}$ stretching from west to east. The coastal area of Pekalongan City has two large river estuaries, namely the Pekalongan River estuary and the Sodetan River estuary (Rachmansyah et al. 2010). In 2017, Pekalongan had a brackish farm area of 379 ha, with 752 aquaculture households in this region (BPS 2018b). More than 1500 small-scale textile industries, namely batik indus- tries, have developed rapidly in this region and may represent an important contributor of Cr enrichment in this area (Apriliani and Widiyanto 2018).

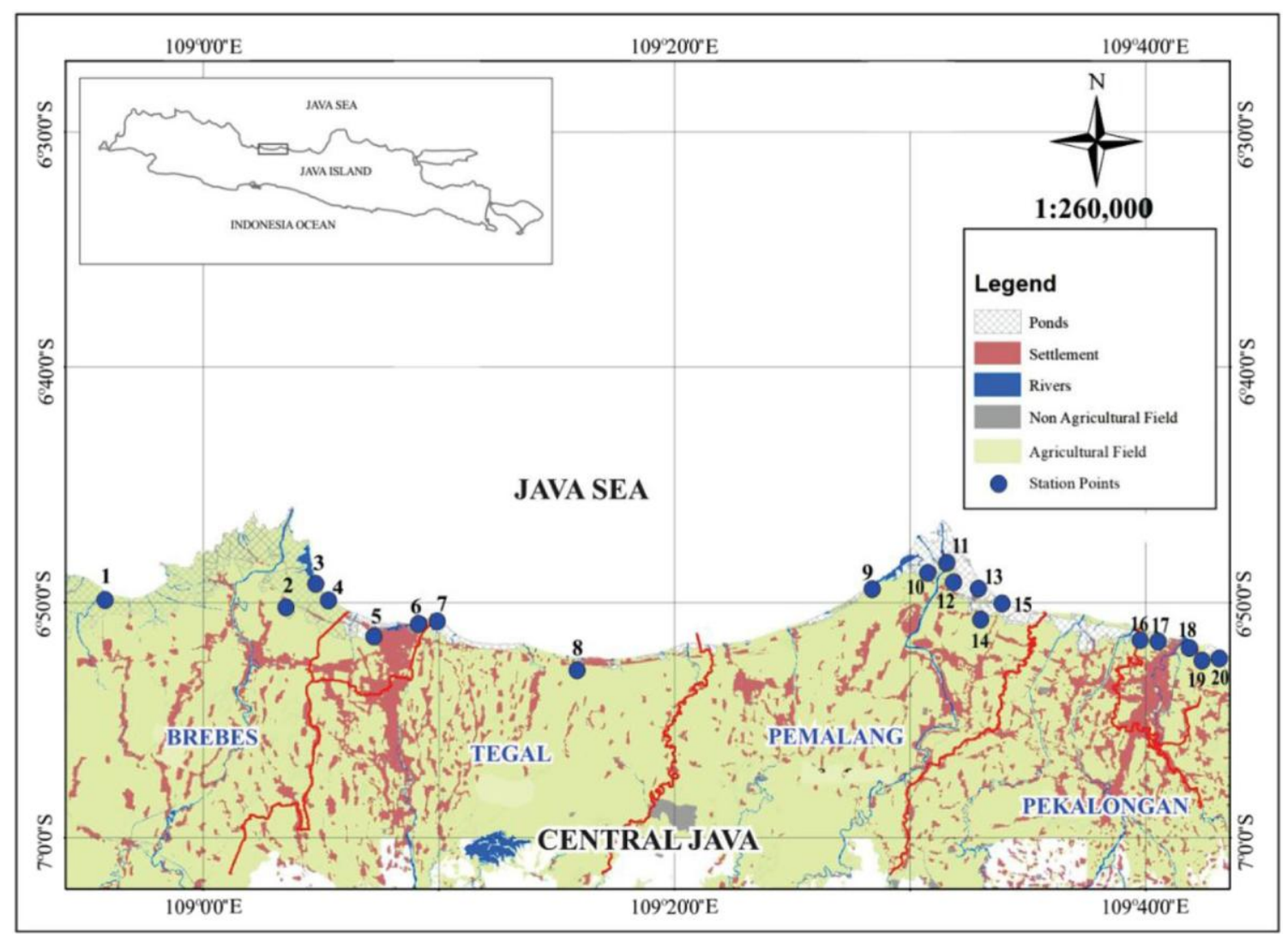

Fig. 1 Study sites. The Brebes (1-4), Tegal (5-8), Pemalang (9-15), and Pekalongan regencies (16-20) 


\section{Sample collection}

Water and sediment samples were collected during the dry season (August 2017), while shrimp samples were collected in both the dry season (simultaneously with water and sedi- ment samples) and wet season (March 2018). In each pond, surface water samples were collected at three different points in the pond, i.e., the inlet (before water enter to the pond), pond (inside the pond), and outlet (after the discharge gates), using polypropylene samplers that were prewashed with 10\% nitric acid and then rinsed with distilled water. The water samples from each pond were prepared as composite samples by mixing water from three subpoints at each collection site, and then, they were transferred in acid-washed plastic bottles, placed in an ice box at $4{ }^{\circ} \mathrm{C}$, and transported to the laboratory. In the laboratory, the samples were filtered using $0.45-\mu \mathrm{m}$ Whatman mixed cellulose ester (MCE) membrane filters, pre- served at $4{ }^{\circ} \mathrm{C}$ in 20 -mL polyethylene bottles, and acidified with $1 \%$ nitric acid $\left(\mathrm{HNO}_{3}\right)$ to $\mathrm{pH} 1.5-2.0$ until analysis.

Regarding the sediments from each pond, bulk samples representing the recently deposited material in the shrimp ponds were collected using a 10-L perforated plastic bucket at the pond siphoning system outlet, and they were collected five times with a 15-min interval to generate subsamples. Dewatering was conducted by decantation, and a composite sample for each pond was created by mixing the 5 subsamples in the same quantities. The solid mixed subsamples of sediment/sludge were immediately placed in labeled polyeth- ylene zip bags and stored in a cool box to minimize microbial degradation during transport to the laboratory. The sediment samples were subsequently freeze-dried to a constant weight (approximately $72 \mathrm{~h}$ ), disaggregated, sieved through 2-mm stainless steel sieves, and then ground using a Retsch RM 200 agate mortar grinder. The sediments were then stored in hermetic plastic vials until analysis.

Shrimp (size 15.02-32.54 g in the dry season and 15.61-31.07 g in the wet season;Electronic Supplementary Material 1, ESM 1) in the intermediate-final stage of the culture cycle (84-110 days of culture (DOC)) were collected using a non- metallic (nylon) net at different points in each pond and then immediately transferred into labeled polyethylene zip bags and stored in a cool box for transport to the laboratory. A composite sample for each pond was created by mixing to- gether the same quantity of each shrimp subsample $(n=10)$. The muscle tissue samples were freeze-dried to a constant weight (approximately $72 \mathrm{~h}$ ), homogenized with a Retsch RM 1000 ultracentrifugal mill, and stored at $-20{ }^{\circ} \mathrm{C}$ until processing for the metal analyses.

\section{Sample digestion and element analysis}

The sediment samples were digested using microwave- assisted acid digestion methods: ISO 11466 (1995). Briefly, approximately $0.5 \mathrm{~g}$ of the ground freeze-dried sediment sample was digested in a microwave digestion system (Milestone Start D) using a mixture of $7 \mathrm{~mL}$ of $37 \%$ hydrochloric acid $(\mathrm{HCl})$ (trace metal grade) and

$3.5 \mathrm{~mL}$ of $65 \% \mathrm{HNO}_{3}$ (trace metal grade) at $200{ }^{\circ} \mathrm{C}$ for $40 \mathrm{~min}$. The obtained solutions were transferred into a $50-\mathrm{mL}$ graduated flask, filtered through a $0.45-\mu \mathrm{m}$ mixed cellulose ester membrane filter, and then stored in high- density polyethylene (HDPE) flasks at $4{ }^{\circ} \mathrm{C}$ (Ahmed et al. 2017). The blank and reference material digestion procedures were also conducted as described above.

The shrimp muscles were ground (Retsch ZM 1000 with tungsten blades) to pass through a 0.2 -mm titanium sieve. Then, $0.5 \mathrm{~g}$ was weighed and placed in a Teflon digestion reactor, to which $3 \mathrm{~mL}$ of concentrated $\mathrm{HCl}$ and $6 \mathrm{~mL}$ of concentrated $\mathrm{HNO}_{3}$ were added (trace metal grade acids). The samples were then digested in a microwave digestion system (Milestone Start D) and mineralized consecutively at $110{ }^{\circ} \mathrm{C}$ for $10 \mathrm{~min}, 150{ }^{\circ} \mathrm{C}$ for $10 \mathrm{~min}$, and $180{ }^{\circ} \mathrm{C}$ for $5 \mathrm{~min}$. The supernatant was then transferred into a $25-\mathrm{mL}$ volumetric flask and filtered using a $0.45-\mu \mathrm{m}$ MCE membrane filter.

\section{Quality assurance and quality control}

The method of analysis was validated using Canadian Certified Reference Materials (STSD-3) for the sediments

and DORM-4 certified reference material for the shrimp sam- ples (National Research Council of Canada). The accuracy was checked by analyzing the certified reference material un- der the same conditions. During the analysis, a verification of the stability of the measurement was carried out every 12 to 15 samples through the measurement of a standard or these qual- ity controls (QCs), and the acceptance was carried out for a maximum drift of 5\%. The blanks and standard solutions were prepared and included in the measurements to define the back- ground correction and any form of unintended contamination during the sample preparation.

The detection limits $\left(\mu \mathrm{g} \mathrm{L}^{-1}\right)$ of $\mathrm{Al}, \mathrm{Cd}, \mathrm{Co}, \mathrm{Cr}, \mathrm{Cu}, \mathrm{Fe}, \mathrm{Mn}, \mathrm{Pb}, \mathrm{Zn}$, and Hg were 3.76, 0.48, 0.99, 6.21, 1.39, 115.36, 0.27, $14.94,13.38$, and 0.45 in the water samples, respectively; $1.43,0.06,0.06,0.21,0.11,3.18,0.12,9.64,0.25$, and 0.02 in the sediment samples, respectively; and 31.37, 0.11, 0.16,0.38, 3.93, 3.29, 0.26, 1.10, 1.02, and 0.02 in the shrimp samples, espectively. The limits of quantification $\left(\mu \mathrm{g} \mathrm{g}^{-1}\right)$ of $\mathrm{Al}, \mathrm{Cd}, \mathrm{Co}, \mathrm{Cr}, \mathrm{Cu}, \mathrm{Fe}, \mathrm{Mn}, \mathrm{Pb}, \mathrm{Zn}$, and $\mathrm{Hg}$ were 12.53, 1.61, 3.31, 20.70, 
$4,62,384.53,0.91,49.80,44.60$, and 1.43 in the water samples, respectively; $4.77,0.19,0.21,0.71,0.35,7.45,0.39,11.74$, 0.82 , and 0.07 in the sediment samples, respectively; and 94.06, $0.36,0.32,1.03,10.50,10.95,0.88,3.68,3.14$, and 0.07 in the shrimp muscles, respectively.

The blank samples containing the acids used for digestion were also processed in the same way. All mineralized samples were then stored at $4{ }^{\circ} \mathrm{C}$ in HDPE flasks until analysis. The metal and trace metal concentrations in the water samples and digestion samples (except mercury) were measured using an inductively coupled plasma atomic emission spectrometry (ICP-AES) system (Horiba Jobin Yvon JY2000-2), while mercury was analyzed after reduction and cold vapor genera- tion using flame atomic absorption spectrometry (FAAS) (Thermo Scientific ICE 3000). Quality assurance, quality con- trols, accuracy, and precision were checked using the standard sediment reference materials (STSD-3, CCRMP-PCMRC, Canada) and fish protein certified reference material (DORM-4, NRC-CNRC, Canada), with accuracies within $100 \pm 10 \%$. The low RSD\% of the concentration values of each metal did not exceed $10 \%$ using the proposed method, thus indicating the method precision.

\section{Occurrence of metals in water bodies and assessment of metal water quality}

The most widely used method for calculating contamination and/or pollution indexes is the Nemerow pollution index, which includes a single pollution index for a particular heavy metal $\left(P_{i}\right)$ and a comprehensive pollution index $\left(P_{n}\right)$ (Dadzie et al. 2020; Yan et al. 2016). The single-factor index reflects the contamination degree of every metal, while the $P_{n}$ reflects the overall effect of all metals on water quality.

The single-factor index method of the Nemerow pollution index $\left(P_{i}\right)$ was calculated using the following equation (Gąsiorek et al. 2017):

$P_{i}=\frac{C_{i}}{S_{i}}$

where $P_{i}$ represents the single-factor index, $C_{i}$ is the measured concentration of metals in water, and $S_{i}$ is the standard value for the aquatic body as the organisms' habitat as proposed by different guidelines (ESM 2). The single-factor pollution in- dex is categorized into five grades, where $P_{i} \leq 1$ represents nonpolluted water, $1<P_{i} \leq 2$ signifies slight pollution, $2<P_{i} \leq 3$ indicates mild pollution, $3<P_{i} \leq 5$ represents moderate pollution, and $P_{i} \geq 5$ indicates heavy pollution (Dadzie et al. 2020).

The comprehensive Nemerow pollution index reflects the degree of contamination from all the measured metals and is calculated as follows (Brady et al. 2015; Liu et al. 2015; Zhang et al. 2017):

$$
P_{n}=\left[\frac{\max _{i} P_{i}^{2}+\underset{i}{\operatorname{avg} P_{i}^{2}}}{2}\right]^{1 / 2}
$$

where $P_{n}$ represents the composite index, which indicates the degree of heavy metal pollution in the water; $\operatorname{avg}_{i \epsilon I} P^{2}$ represents the average value of Pi2; and max Pi2 is the maximum value of Pi2. Liu et al. (2015) categorized the Pn values as follows: $\mathrm{Pn}<0.7$, uncontaminated water; $0.7 \leq \mathrm{Pn} \leq 0.7$, under the threat of contamination; and $\mathrm{Pn}>1$, heavily contaminated water.

\section{Assessment of the sediment}

\section{Sediment quality guidelines}

A comparison of the measured concentrations of various con-taminants within the sediments with these guideline values will provide a basic indication of the degree of contamination and likely impact on the ecosystem. In the present study, two sets of sediment quality guidelines (SQGs), i.e., the threshold effects level (TEL), probable effects level (PEL), effects range low (ERL), and effects range median (ERM), from the Canadian sediment quality guidelines were applied to assess the possible risk from metal contamination in the sediment (CCME 2007).

\section{Enrichment factor}

The enrichment factor (EF) is a geochemical index used to evaluate a possible source of anthropogenic activities for trace metals using the normalization of metal concentrations by uncontaminated background values (Dickinson et al. 1996). TheEF was calculated based on the following equation (Gargouri et al. 2018; Nowrouzi and Pourkhabbaz 2014): 


$$
\mathrm{EF}=\frac{\left(C_{i} / C_{\mathrm{Fe}}\right)_{\mathrm{s}}}{\left(C_{i} / C_{\mathrm{Fe}}\right)_{\mathrm{r}}}
$$

where $\mathrm{EF}$ is the enrichment factor of an element, $\left(C_{i} / C_{\mathrm{Fe}}\right)_{\mathrm{s}}$ represents the metal/Fe ratio of the sample concentrations at each sampling point, and $\left(C_{i} / C_{\mathrm{Fe}}\right)_{\mathrm{r}}$ is the corresponding element/Fe ratio of the concentrations in the reference sedi- ments. Ideally, the reference sediment values for metals would be estimated from in situ sediments, although in the absence of these data, earth's crust values can sometimes be substituted as shown in Abrahim and Parker (2008). For this study, the average shale concentration of the sedimentary rock in earth's crust (Turekian and Wedepohl 1961) was adopted as the base- line value. In this work, we employed $\mathrm{Fe}$ as a conservative element for geochemical normalization of the heavy metal data in the EF calculation because $\mathrm{Fe}$ is one of the three con- servative elements generally used (Ganugapenta et al. 2018; Pandey et al. 2015). The six contaminants were categorized based on their enrichment factors.

\section{Geoaccumulation index}

The geoaccumulation index (Igeo) has been widely used to evaluate the degree of metal contamination or pollution in terrestrial, aquatic, and marine environments (Kabir et al. 2011; Muller 1969) and is calculated using the following equation:

$$
I_{\text {geo }}=\log _{2}\left[\frac{C_{i}}{1.5 B_{i}}\right]
$$

where $\mathrm{Ci}$ is the measured concentration of the examined metal (i) in the sample and $\mathrm{Bi}$ is the background concentration of the corresponding metal (i). In this study, we used the following as the background concentrations: $17 \mathrm{mg} \mathrm{kg}-1$ for Co and $\mathrm{Pb}$ (McLennan 2001), $35 \mathrm{mg} \mathrm{kg}-1$ for Cr, $25 \mathrm{mg} \mathrm{kg}-1$ for Cu (Ranjan et al. 2018), 56,000 mg kg-1 for Fe (Taylor 1964), 292.2 mg kg-1 for Mn (Xavier et al. 2017), and $59.11 \mathrm{mg} \mathrm{kg-1} \mathrm{for} \mathrm{Zn} \mathrm{(Yang} \mathrm{et} \mathrm{al.} \mathrm{2018).} \mathrm{A} \mathrm{factor} \mathrm{of} 1.5$ was applied to the geochemical background concentration to minimize the pos-sible variations in the background value of a given metal due to terrigenous effects (Lizárraga-Mendiola et al. 2008; Lu et al. 2009).

\section{Contamination factor and pollution load index}

The contamination factor (CF) is used to determine the con-tamination status of a sediment and is the ratio of the concentration of a metal in the sediment sample to that in the back-ground. The CF was calculated using the following equation (Hakanson 1980):

$$
\mathrm{CF}=\frac{C_{\text {metal }}}{C_{\text {background }}}
$$

The CF values were categorized as follows: CF $<1$, low degree of contamination; $1 \leq \mathrm{CF}<3$, moderate degree of contamination; $3 \leq \mathrm{CF} \leq 6$, considerable degree of contami-nation; and $\mathrm{CF}>6$, very high degree of contamination (Satapathy and Panda 2015).

To estimate the overall pollution status of the samples, the pollution load index (PLI) has also been used. The PLI of a set of $\mathrm{n}$ polluting elements is defined as a value calculated from the geometric mean of the respective contamination factors of those elements using the following equation (Qing et al. 2015):

$$
\text { PLI station }=\sqrt[n]{\mathrm{CF} 1 \times \mathrm{CF} 2 \ldots \times \mathrm{CF} n}
$$

where CF represents the contamination factor of a metal and $\mathrm{n}$ represents a specific metal's contamination factor. The PLI values were used to classify samples as unpolluted $(P L I \leq 1)$, moderately polluted $(P L I=1-3)$, highly polluted $(P L I=3-5)$, or very highly polluted $(\mathrm{PLI}>5)$.

To determine the contamination status in the overall zone studied, we used the following relationship:

$$
\begin{aligned}
& \text { PLI zone }=\sqrt[n]{\text { PLI station } 1 \times \text { PLI station } 2 \ldots \times \text { PLI station } n} \\
& \text { Potential ecological risk index and integrated ecological risk index }
\end{aligned}
$$

The potential ecological risk of each metal was calculated by the Hakanson equation as previously described by Wu et al. 
(2017) :

$$
E_{\mathrm{r}}^{i}=T_{\mathrm{r}}^{i} \times C_{\mathrm{f}}^{i}
$$

where Eir is the coefficient of potential ecological risk from metal $i$, Tir is the toxicity coefficient of metal i,and Cif is the accumulation coefficient (contamination factor) of metal $\mathrm{i}$. The toxic response factors used were as follows: $\mathrm{Cu}=\mathrm{Pb}=5, \mathrm{Cr}$ $=2, \mathrm{Zn}=1, \mathrm{Co}=5$, and $\mathrm{Mn}=1$ (Hakanson 1980).

To evaluate the overall ecological risk status (integrated potential ecological risk index (RI)) of the sediment, the fol-lowing equation is widely used:

$$
\mathrm{RI}=\sum_{i=1}^{n} E_{\mathrm{r}}^{i}
$$

where $\mathrm{RI}$ is the integrated potential ecological risk factor for the metal in sediments. The terminology used to describe the ecological risk index is as previously defined (Hakanson 1980).

Occurrence and human health risk assessment of the shrimp

\section{Estimated daily intake}

The estimated daily intake (EDI) of the different metals was evaluated based on the tissue concentrations of each metal in the shrimp and the average daily shrimp ingestion rate (Santos et al. 2004). The EDI represents the estimated daily intake of metal through the consumption of shrimp by an adult human (in $\mathrm{mg} \mathrm{kg}-1$ day-1). The following relationship was used to calculatethe EDI(Liu etal. 2018):

$$
\mathrm{EDI}=\frac{\mathrm{EF} \times \mathrm{ED} \times \mathrm{IR} \times C_{m}}{\mathrm{WAB} \times \mathrm{TA}}
$$

where $E F$ is the exposure frequency ( 365 days year -1$)$, ED is the exposure duration (70 years, equivalent to the average life span as used by Anandkumar et al. (2018), Liu et al. (2018), and Keshavarzi et al. (2018)), IR is the ingestion rate (g day-1), $\mathrm{Cm}$ is the concentration of metal in the shrimp (mg kg-1 dw), WAB is the average adult body weight $(\mathrm{kg})$, and TA is the average lifetime ( 70 years $\times 365$ days year -1 ,

i.e., 25,550$)$. The daily consumption rate was set at $20.67 \mathrm{~g}$ person-1 day-1 as per the report of the Statistics Indonesia database for the fish and shrimp rates of consump-tion (BPS 2016), while the average adult body weight in Asia (including Indonesia) was assumed to be $57.7 \mathrm{~kg}$ (Walpole et al. 2012). A value of 4.54 was used as the conversion factor to convert the dry weight to wet weight based on a shrimp moisture content of 78\% (Qiu et al. 2017).

\section{Target hazard quotient}

The target hazard quotient (THQ) is defined as the maximum tolerable daily intake of a specific metal that does not result in any deleterious health effects. In the present study, we used the THQ to assess the human health risk level due to pollutant exposure from consuming metal-contaminated shrimp. The THQ was calculated as the ratio of the average daily intake of a specific chemical over a lifetime to the oral reference dose (RfD) of the trace metal. This metric is an estimate of the daily oral exposure by a human that does not have an appreciable risk of deleterious effects during a lifetime (USEPA 2002).

The following equation was used to determine the THQ (Anandkumar et al. 2018; Liu et al. 2018):

$$
\mathrm{THQ}=\frac{\mathrm{EDI}}{\mathrm{RfD}}
$$

Oral RfDs (mg kg-1 day-1) of 0.001, 0.14, and 0.3 were used for Cd, Mn, and Zn, respectively, and these values were based on US EPA guidelines (USEPA 2018): 0.03 was used for Co (Finley et al. 2012), 0.003 was used for Cr (Liu et al. 2018; Zhaoetal. 2016; Yabanli and Alparslan2015), 0.02 was used for Cu (Ahmed et al. 2015), 0.004 was used for $\mathrm{Pb}$, and 0.0003 was used for $\mathrm{Hg}$ (Yabanli and Alparslan 2015); these values were 
used to assess the exposure hazards from shrimp consumption. THQ values of $<1$ indicate that adverse health effects are unlikely to occur, and THQ values of $>1$ indicate that the consumer population has potential health risks.

\section{Hazard index}

Since exposure is usually not associated with a single toxicant, the hazard index $(\mathrm{HI})$ was developed from the THQs and expressed as the sum of the hazard quotients (USEPA 2018). The hazard index derived for the shrimp was deter-mined according to the following equation:

$$
\mathrm{HI}=\sum_{i=1}^{n} \mathrm{THQ}_{i}
$$

where THQi is the target hazard quotient of an individual metal and $\mathrm{HI}$ is the total hazard index for all metals. In the present study, $\mathrm{HI}$ is the total hazard index for eight metals $(\mathrm{Cd}, \mathrm{Cr}, \mathrm{Co}, \mathrm{Cu}, \mathrm{Mn}, \mathrm{Pb}, \mathrm{Zn}, \mathrm{Hg}$ ). $\mathrm{HI}>1$ indicates a potential for an adverse effect on human health.

\section{Carcinogenic risk}

The carcinogenic risk was estimated as the incremental prob-ability of an individual developing cancer over a lifetime of exposure to a potential carcinogen by employing a target can-cer risk value (USEPA 1989). The carcinogenic health risks related to the consumption of seafood were measured based on the target cancer risk (TR), which was calculated as follows:

$$
\mathrm{TR}=\mathrm{EDI} \times \mathrm{CSFo} \times 10^{-3}
$$

where CSFo is the oral carcinogenic slope factor from the Integrated Risk Information System database. For $\mathrm{Cr}$ and $\mathrm{Pb}$, the slope values were $0.5 \mathrm{mg} \mathrm{kg}-1$ day-1 and $0.0085 \mathrm{mg} \mathrm{kg}-1$ day-1, respectively. According to the New York State Department of Health (NYSDOH 2007), the threshold TR values for categorizing risk are as follows: TR $\leq 10-6$, lowrisk;10-4 to 10-3, moderate risk; $10-3$ to $10-1$, high risk; and $\geq 10-1$, veryhighrisk.

\section{Statistical analysis}

A principal component analysis (PCA) was applied to the results to establish the significance at a probability of $95 \%$ for the spatial and temporal variations in the metal concentrations in the water, sediments, and shrimp. The possible relationship between the different variables was estimated by determining the correlation coefficients. A high correlation coefficient implies a strong relationship between variables, and although this value is not a measure of quantitative changes of one variable with respect to the other, it is a measure of the intensity of the association between the two variables. All statistical analyses were performed using R statistical software.

\section{Results and discussion}

The selected shrimp farms were originally constructed based on single pond operators in which the operations were modified to include reservoirs to treat water from supply canals (river, coastal, or piped from a well) before use. However, the system had no wastewater treatment system for effluents discharged from the culture ponds during operation and har- vest. Generally, the ponds were arranged in rows, with dis- charge canals on opposite sides. The farms were operated with a pond size of 1000-3000 $\mathrm{m}^{2}$, a shrimp density of $80-150 \mathrm{~m}^{-2}$, a culture period of 84-110 days, a feeding period for 4-5 times, a feed conversion ratio (FCR) of 1.2-1.8, and a shrimp size of 15.02-32.54 g piece ${ }^{-1}$. The operation applied a 3-10\% water exchange periodically. The technology used for white shrimp culture consists of middle (semi-intensive) and high (intensive) levels. The shrimp farm characteristics and management activities during this study are summarized in ESM 3.

Occurrence of metals in the water and assessment of metal water quality

The concentrations of metals observed in the water samples are displayed in Fig. 2. The metal concentrations revealed that $\mathrm{Zn}$ 
and $\mathrm{Fe}$ were the dominant metals in shrimp ponds in Brebes and Tegal, with the concentrations ranging from 49 to $681 \mu \mathrm{g}$ $\mathrm{L}^{-1}$ and from 38 to $169 \mu \mathrm{g} \mathrm{L}^{-1}$ for $\mathrm{Zn}$, respectively, and from 68 to $279 \mu \mathrm{g} \mathrm{L}^{-1}$ and from 35 to $404 \mu \mathrm{g} \mathrm{L}^{-1}$ for Fe, respectively. $\mathrm{Mn}$ and $\mathrm{Fe}$ were also the dominant metals in Pekalongan and Pemalang, and the concentrations ranged from 82 to $537 \mu \mathrm{g}$ $\mathrm{L}^{-1}$ and from 123 to $2939 \mu \mathrm{g} \mathrm{L}^{-1}$ for $\mathrm{Fe}$, respectively, and from 48.8 to $1428.7 \mu \mathrm{g} \mathrm{L}^{-1}$ and from 39.8 to $1336.8 \mu \mathrm{g} \mathrm{L}^{-1}$ for Mn, respectively. In the present study, $\mathrm{Pb}$ was not detected in the water samples from any of the studied areas (LOD of $14.94 \mu \mathrm{g}$ $\mathrm{L}^{-1}$ ). The $\mathrm{Zn}$ concentrations showed similar trends in all regions and increased from the inlets to the ponds and eventually decreased from the ponds to the outlets. These trends indicated the application of metals in aquaculture systems.

One possible source for various metals is from foods enriched by some metals. Katya et al. (2016) investigated the content of trace minerals of the commercial sources of diets applied to L. vannamei and found levels of $\mathrm{Zn}$ in the concentration of 29.3-182 ppm. Another study conducted by León-Cañedo et al. (2017) found that the main source of $\mathrm{Cu}$ and $\mathrm{Zn}$ metals in a simulated culture system with L. vannamei was the diet, which accounted for $91.8 \%$ of $\mathrm{Cu}$ and $97.0 \%$ of $\mathrm{Zn}$. $\mathrm{Zn}$ is known as an essential nutrient for many physiological functions, such as growth, develop- ment (Watanabe et al. 1997), and immune function (Rink and Kirchner 2000). Similarly, Lin et al. (2013) found that zinc significantly reduced the cumulative mortality of L. vannamei against Vibrio harveyi, indicating an enhance- ment of the immune system and hence an improved resistance of the shrimp. Zn intake could reduce Cd toxicity; thus, the presence of zinc in water plays an important role for shrimp (Brzóska and Moniuszko-Jakoniuk 2001).

Mn is ubiquitous in the environment and accounts for ap- proximately $0.1 \%$ of earth's crust, and it can also be released into water by discharge from aquaculture activities and industrial activities and the combustion of fossil fuels. Katya et al. (2016) found $\mathrm{Mn}$ as one of trace minerals in the com- mercial diet sources for L. vannamei, and the concentration ranged from 25.9 to $132.2 \mathrm{ppm}$. Mn is essential at low con- centrations but becomes lethal at higher concentrations (Srichandan et al. 2016). Municipal wastewater discharges, sewage sludge, and emissions from alloys are additional sources of Mn in the environment (WHO 2004). The opera- tion of some metallurgical industries may contribute to Mn contamination in the water in this study area, since this indus- try potentially releases Mn into the environment (Rahman et al. 2014). Some metallurgical industries are established in Brebes (BPS 2018a), Tegal (BPS 2018d), and Pekalongan (BPS 2018b).

In the case of $\mathrm{Cu}$, our results showed that $\mathrm{Cu}$ concentra- tions $\left(\mu \mathrm{g} \mathrm{L}^{-1}\right)$ generally increased from $1.20,2.84$, and 2.63 in the inlets to 1.22, 3.15, and 3.08 in the ponds in Brebes, Pekalongan, and Pemalang, respectively (ESM 4). These re- sults were slightly higher than those of Wang et al. (2014), who found that the $\mathrm{Cu}$ concentration ranged from $0.52 \pm 0.33$ to $2.49 \pm 0.73$ $\mu \mathrm{g} \mathrm{L}^{-1}$ in Maluan Bay, China, which is the habitat of L. vannamei (Wang et al. 2014). The concentrations were also lower than the concentrations that may cause mor- tality and induce adverse shrimp physiological responses. Frías-Espericueta et al. (2008b) determined the survival and possible histological alterations in the gills and hepatopancre- as of L. vannamei juveniles exposed to copper sulfate and found that the mortality of shrimp juveniles during $96 \mathrm{~h}$ of exposure was $50 \%$ (96-h $\left.\mathrm{LC}_{50}\right)$ at a concentration of

$35.12 \mathrm{mg} \mathrm{L}^{-1}$, whereas the absence of pillar cells, loss of regular structure of the cuticular epithelium, and multifocal necrosis were observed after 3 weeks of exposure to a con- centration of $1.756 \mathrm{mg} \mathrm{L}^{-1}$. Cu-related histological alterations were also reported by Soegianto et al. (2013) and Qian et al. (2020) in L. vannamei juveniles. Soegianto et al. (2013) found that after 15 days of exposure to $0.675 \mathrm{mg} \mathrm{L}^{-1}$, tissue hyper- plasia was evident in the filaments, which resulted in a narrowing of the hemolymphatic lacunae. Furthermore, ne-crosis and loss of hemolymphatic lacunae were observed in the gills of shrimp exposed to $1.325 \mathrm{mg} \mathrm{L}^{-1}$ and $2.010 \mathrm{mg} \mathrm{L}^{-1}$. A study by Qian et al. (2020) indicated that $\mathrm{Cu}$ concentrations above $0.2 \mathrm{mg} \mathrm{L}^{-1}$ can decrease growth performance, $\mathrm{Cu}^{2+}$ concentrations above $0.5 \mathrm{mg} \mathrm{L}^{-1}$ damaged the hepatopancreas histology, and $\mathrm{Cu}^{2+}$ concentrations above $0.5 \mathrm{mg} \mathrm{L}^{-1}$ can reduce the hemolymph immunologic function of $L$. vannamei. Our result is also below the concentration of metal mixtures $(\mathrm{Cd}, \mathrm{Cu}, \mathrm{Fe}, \mathrm{Mn}, \mathrm{Pb}$, and $\mathrm{Zn})$ that might cause histological and structural damages to the gills, epipodites, hepatopancreas, and midgut of L. vannamei juveniles (Frías- Espericueta et al. 2008a). 

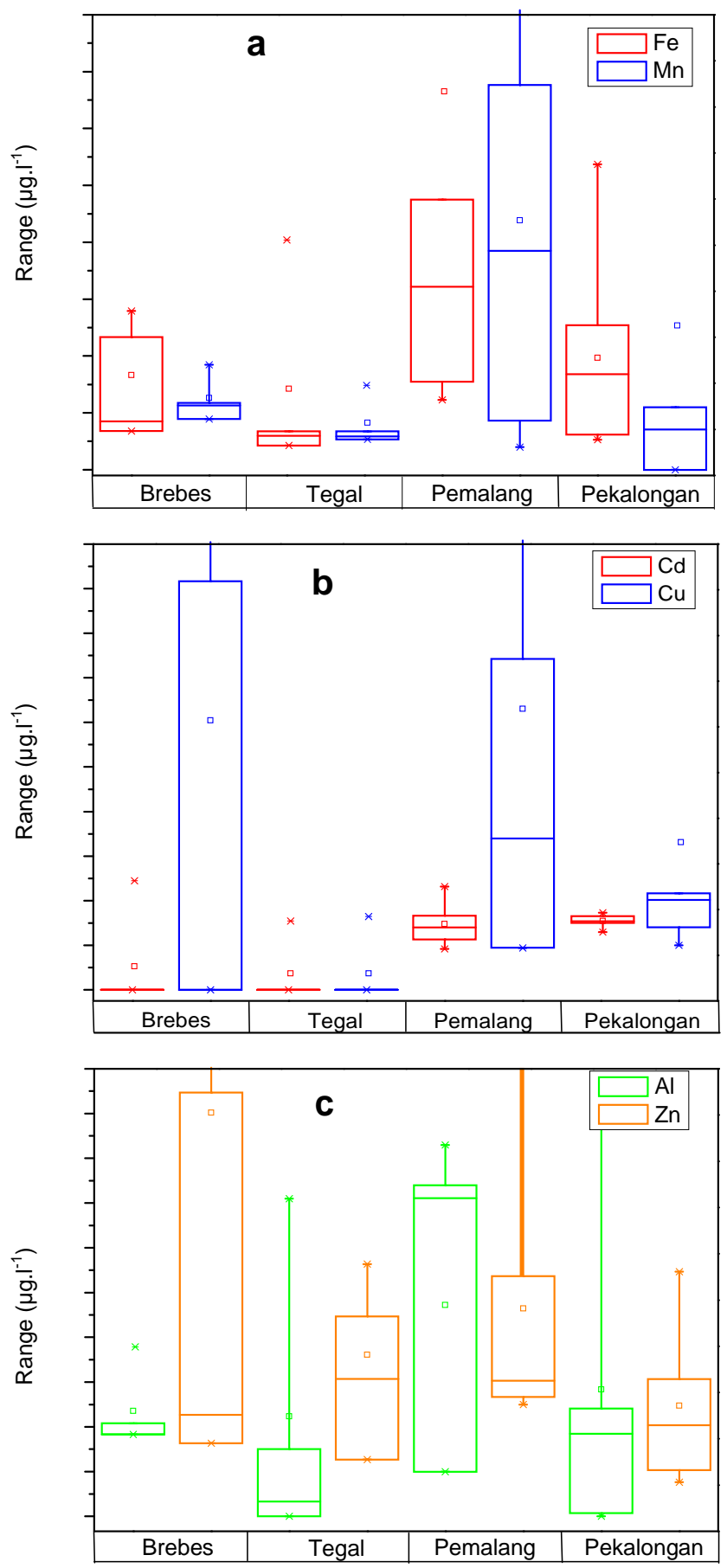

Fig. 2 Metal concentrations $\left(\mu \mathrm{g} \mathrm{L}^{-1}\right)$ of a Fe and $\mathrm{Mn}, \mathrm{b} \mathrm{Cd}$ and $\mathrm{Cu}$, and c $\mathrm{Al}$ and $\mathrm{Zn}$ in the surface water of shrimp ponds on the northern coast of Central Java 
Boyd and Massaut (1999) reported that some trace metals are present as natural components in feeds, impurities in fertilizers, or active substances in pesticides. Katya et al. (2016) analyzed the content of trace minerals of the tradi- tional inorganic and commercial sources of diets applied to

L. vannamei and showed that the $\mathrm{Cu}$ concentration ranged from 12.8 to $185 \mathrm{ppm}$. Yuan et al. (2019) reported that $\mathrm{Cu}$ in copper sulfate and chelated copper compounds are very effective algicides, which are applied to ponds to reduce the abundance of nuisance aquatic plants. Boyd and Massaut (1999) reported that some trace metals are present as natural components in feeds, impurities in fertilizers, or active sub- stances in pesticides. Katya et al. (2016) analyzed the con- tent of trace minerals of the traditional inorganic and com- mercial sources of diets applied to L. vannamei and showed that the $\mathrm{Cu}$ concentration ranged from 12.8 to $185 \mathrm{ppm}$. Cu was also presented in the chemical additives (lime and chloride) applied to shrimp farms at concentrations ranging from 1.9 to $3.3 \mathrm{\mu g} \mathrm{g}^{-1} \mathrm{dw}$ (Lacerda et al. 2006). However, they concluded that aquafeeds are, by far, the largest con- tributor of $\mathrm{Cu}$ to shrimp ponds due to the higher $\mathrm{Cu}$ con- centrations and the larger amount used. The total $\mathrm{Cu}$ load from aquafeeds and other products applied to ponds contrib- uted $194.5 \mathrm{~g} \mathrm{ha}^{-1} \mathrm{cycle}^{-1}$.

It is well documented that in aquaculture systems of

L. vannamei, dietary $\mathrm{Cu}$ (along with zinc) plays an important role as a promoter of growth and immune function (Cheng et al. 2014). Davis et al. (1993) showed that the weight of shrimp increased in response to copper supplementation, indicating a dietary copper requirement for shrimp growth and survival. Furthermore, Yuan et al. (2019) demonstrated that dietary chelated copper is effective at improving oxidation resistance and nonspecific immunity of L.vannamei.

To evaluate the metal contamination, the single-factor pol- lution index $\left(P_{i}\right)$ and the Nemerow pollution index $\left(P_{n}\right)$ were calculated, and the results are shown in Table 1, ESM 5, and ESM 6. A comparison with the grades of the $P_{i}$ showed that the surface water of shrimp farms was generally contaminated by $\mathrm{Mn}$ and $\mathrm{Cd}$. The $P_{i}$ and $P_{n}$ have been broadly used to evaluate the heavy metal contamination in water and sediment. For example, Zhong et al. (2015) employed these two risk assessment models to determine the heavy metal contamination in groundwater for drinking purposes, Dadzie et al. (2020) applied these indexes to determine the contami- nation status of water from lake and rivers, and Zhang et al. (2017) used these indexes to evaluate the heavy metal con- tamination of marine reserve waters. Furthermore, many au- thors have used the $P_{i}$ and $P_{n}$ indexes to evaluate heavy metal contamination in sediment (Asare-Donkor et al. 2018; Yavar Ashayeri and Keshavarzi 2019; Mirza et al. 2019; Yan et al. 2016). In the present study, we applied $P_{i}$ and $P_{n}$ to assess the contamination level of metals in water for shrimp as abrackish aquatic organism, and $S_{i}$ is the standard value for aquatic organisms.

Kowalska et al. (2018) stated that $P_{i}$ and $P_{n}$ can be used to highlight which heavy metal represents the highest threat at the site. In addition, since different heavy metals may have impacts on one site, Yan et al. (2016) stated that the $P_{n}$ index could provide a reasonable interpretation of the heavy metal contamination at each site as a whole.

With regard to the health of the shrimp ponds, for the shrimp L. vannamei, Boyd (2009) and Prapaiwong and Boyd (2014) have proposed safe and acceptable metal levels. Our study showed that metal contamination was within the safe or acceptable levels for the shrimp ponds' carrying ca- pacities. However, $\mathrm{Cu}$ and combinations of various metals may represent a hazard to the juvenile shrimp $(5-6.5 \mathrm{~cm})$, and a previous study showed that histological effects may be observed at $2.5 \mu \mathrm{g} \mathrm{L}{ }^{-1}$ of Cu (Fig. 2) (Frías-Espericueta et al. 2008a, b); unfortunately, such analyses are beyond the scope of our study. 
Table 1 Single-factor pollution index for six metals in the surface water of shrimp farm

\begin{tabular}{|c|c|c|c|c|c|c|c|c|c|c|c|c|c|c|}
\hline \multirow{2}{*}{ Region } & \multirow{2}{*}{ sub-site } & \multirow{2}{*}{$\begin{array}{c}\min \& \\
\max \end{array}$} & \multicolumn{11}{|c|}{ Range of $\mathrm{Pi}$ value } & \multirow[b]{2}{*}{ status } \\
\hline & & & $\mathrm{Cd}$ & status & $\mathrm{Cr}$ & status & $\mathrm{Cu}$ & status & $\mathrm{Mn}$ & status & $\mathrm{Pb}$ & status & $\mathrm{Zn}$ & \\
\hline \multirow{6}{*}{ Brebes } & \multirow{2}{*}{ Inlet } & $\min$ & 0.00 & $\mathrm{np}$ & 0.00 & $\mathrm{np}$ & 0.32 & $\mathrm{np}$ & 5.60 & hp & 0.00 & $n p$ & 0.50 & $\mathrm{np}$ \\
\hline & & $\max$ & 4.80 & mop & 0.00 & $\mathrm{np}$ & 0.89 & $\mathrm{np}$ & 10.07 & hp & 0.00 & $\mathrm{np}$ & 4.04 & mop \\
\hline & \multirow{2}{*}{ pond } & $\min$ & 0.00 & $\mathrm{np}$ & 0.00 & $\mathrm{np}$ & 0.00 & $\mathrm{np}$ & 0.89 & $\mathrm{np}$ & 0.00 & $\mathrm{np}$ & 0.98 & $\mathrm{np}$ \\
\hline & & $\max$ & 4.88 & mop & 0.00 & $\mathrm{np}$ & 3.75 & mop & 1.85 & $\mathrm{sp}$ & 0.00 & $n p$ & 13.62 & hp \\
\hline & \multirow{2}{*}{ outlet } & $\min$ & 0.00 & $\mathrm{np}$ & 0.00 & $\mathrm{np}$ & 0.60 & $\mathrm{np}$ & 7.99 & hp & 0.00 & $\mathrm{np}$ & 0.66 & $\mathrm{np}$ \\
\hline & & $\max$ & 4.27 & mop & 2.02 & $\mathrm{mp}$ & 2.47 & $\mathrm{mp}$ & 34.33 & $\mathrm{hp}$ & 0.00 & $\mathrm{np}$ & 2.84 & $\mathrm{mp}$ \\
\hline \multirow{6}{*}{ Tegal } & \multirow{2}{*}{ Inlet } & $\min$ & 0.00 & $\mathrm{np}$ & 0.00 & $\mathrm{np}$ & 0.00 & $\mathrm{np}$ & 0.16 & $\mathrm{np}$ & 0.00 & $\mathrm{np}$ & 0.88 & $\mathrm{np}$ \\
\hline & & $\max$ & 4.48 & mop & 0.00 & $\mathrm{np}$ & 0.30 & $\mathrm{np}$ & 5.31 & $\mathrm{hp}$ & 0.00 & $\mathrm{np}$ & 1.30 & $\mathrm{sp}$ \\
\hline & \multirow{2}{*}{ pond } & $\min$ & 0.00 & $\mathrm{np}$ & 0.00 & $\mathrm{np}$ & 0.00 & $\mathrm{np}$ & 0.48 & $\mathrm{np}$ & 0.00 & $\mathrm{np}$ & 0.76 & $\mathrm{np}$ \\
\hline & & $\max$ & 3.25 & mop & 0.00 & $\mathrm{np}$ & 0.43 & $\mathrm{np}$ & 1.45 & $\mathrm{sp}$ & 0.00 & $\mathrm{np}$ & 3.38 & $\overline{\text { mop }}$ \\
\hline & \multirow{2}{*}{ outlet } & $\min$ & 0.00 & $\mathrm{np}$ & 0.00 & $\mathrm{np}$ & 0.00 & $\mathrm{np}$ & 0.90 & $\mathrm{np}$ & 0.00 & $\mathrm{np}$ & 0.84 & $n p$ \\
\hline & & $\max$ & 3.44 & mop & 0.00 & $\mathrm{np}$ & 0.20 & $\mathrm{np}$ & 27.30 & $\mathrm{hp}$ & 0.00 & $\mathrm{np}$ & 3.70 & mop \\
\hline \multirow{6}{*}{ Pemalang } & \multirow{2}{*}{ Inlet } & $\min$ & 1.56 & $\mathrm{sp}$ & 0.00 & $\mathrm{np}$ & 0.00 & $\mathrm{np}$ & 0.09 & $\mathrm{np}$ & 0.00 & $\mathrm{np}$ & 0.00 & $\mathrm{np}$ \\
\hline & & $\max$ & 3.93 & mop & 0.00 & $\mathrm{np}$ & 2.08 & $m p$ & 42.19 & hp & 0.00 & $\mathrm{np}$ & 5.40 & $\mathrm{hp}$ \\
\hline & \multirow{2}{*}{ pond } & $\min$ & 1.96 & $\mathrm{sp}$ & 0.00 & $\mathrm{np}$ & 0.24 & $\mathrm{np}$ & 0.40 & $\mathrm{np}$ & 0.00 & $\mathrm{np}$ & 1.50 & $\mathrm{sp}$ \\
\hline & & $\max$ & 4.76 & mop & 0.00 & $\mathrm{np}$ & 5.68 & hp & 13.37 & $\mathrm{hp}$ & 0.00 & $\mathrm{np}$ & 7.64 & $\mathrm{hp}$ \\
\hline & \multirow{2}{*}{ outlet } & $\min$ & 0.00 & $\mathrm{np}$ & 0.00 & $\mathrm{np}$ & 0.00 & $\mathrm{np}$ & 0.57 & $\mathrm{np}$ & 0.00 & $\mathrm{np}$ & 0.44 & $\mathrm{np}$ \\
\hline & & $\max$ & 5.09 & hp & 0.00 & $\mathrm{np}$ & 4.19 & mop & 23.03 & hp & 0.00 & $\mathrm{np}$ & 5.74 & $\mathrm{hp}$ \\
\hline \multirow{6}{*}{ Pekalongan } & \multirow{2}{*}{ Inlet } & $\min$ & 2.20 & $\mathrm{mp}$ & 0.00 & $\mathrm{np}$ & 0.29 & $\mathrm{np}$ & 0.35 & $\mathrm{np}$ & 0.00 & $n p$ & 0.60 & $\mathrm{np}$ \\
\hline & & $\max$ & 3.30 & mop & 0.00 & $n p$ & 0.51 & $\mathrm{np}$ & 2.42 & $m p$ & 0.00 & $\mathrm{np}$ & 1.48 & $\mathrm{sp}$ \\
\hline & \multirow{2}{*}{ pond } & $\min$ & 2.65 & $\mathrm{mp}$ & 0.00 & $\mathrm{np}$ & 0.25 & $\mathrm{np}$ & 0.49 & $\mathrm{np}$ & 0.00 & $\mathrm{np}$ & 0.46 & $\mathrm{np}$ \\
\hline & & $\max$ & 3.52 & mop & 0.00 & $\mathrm{np}$ & 2.44 & $\mathrm{mp}$ & 14.29 & hp & 0.00 & $\mathrm{np}$ & 3.28 & mop \\
\hline & \multirow{2}{*}{ outlet } & $\min$ & 0.63 & $\mathrm{np}$ & 0.00 & $\mathrm{np}$ & 0.00 & $\mathrm{np}$ & 0.52 & $\mathrm{np}$ & 0.00 & $\mathrm{np}$ & 0.28 & $\mathrm{np}$ \\
\hline & & $\max$ & 3.34 & mop & 0.00 & $\mathrm{np}$ & 0.57 & $\mathrm{np}$ & 5.44 & $\mathrm{hp}$ & 0.00 & $\mathrm{np}$ & 2.10 & $\mathrm{mp}$ \\
\hline
\end{tabular}

$n p$ nonpollution (green), $s p$ slight pollution (pink), $m p$ mild pollution (yellow), mop moderate pollution (blue), $h p$ heavy pollution (red) 


\section{Occurrence of metals in the sediment}

The maximum mean $\pm \mathrm{SD}$, and minimum concentrations $\left(\mathrm{mg} \mathrm{kg}^{-1} \mathrm{dw}\right)$ of the metals in the sediments as well as a comparison with the SQGs are provided in Table 2. The metal concentrations in the shrimp pond sediment showed that Cr, $\mathrm{Cu}, \mathrm{Pb}$, and $\mathrm{Zn}$ were below the ERL based on the Canadian sediment quality guidelines, which were 81, 34, 46.7, and 150 $\mathrm{mg} \mathrm{kg}{ }^{-1} \mathrm{dw}$ for $\mathrm{Cr}, \mathrm{Cu}, \mathrm{Pb}$, and $\mathrm{Zn}$, respectively. According to the US EPA standard, the sediment was moder- ately polluted (25-75 $\mathrm{mg} \mathrm{kg}^{-1} \mathrm{dw}$ ) by $\mathrm{Cr}$ (all regions), $\mathrm{Cu}$ (except in the Pekalongan region), and $\mathrm{Zn}$ (Brebes and Tegal regions).

Table 2 Comparison between the sediment quality guidelines (SQGs) and metal concentrations ( $\mathrm{mg} \mathrm{kg}^{-1}$ dry weight) in the shrimp pond sediment

\begin{tabular}{|c|c|c|c|c|}
\hline Region & $\mathrm{Cr}$ & $\mathrm{Cu}$ & $\mathrm{Pb}$ & $\mathrm{Zn}$ \\
\hline \multicolumn{5}{|l|}{ Brebes } \\
\hline Mean & $55.5 \pm 0.8$ & $31.8 \pm 4.2$ & $13.9 \pm 1.2$ & $93.7 \pm 1.6$ \\
\hline Min & 54.7 & 27 & 12.2 & 91.6 \\
\hline Max & 56.4 & 37.2 & 15 & 95.3 \\
\hline \multicolumn{5}{|l|}{ Tegal } \\
\hline Mean & $46.6 \pm 4.53$ & $51.825 \pm 9.11$ & $14.1 \pm 1.11$ & $99 \pm 4.86$ \\
\hline Min & 39.9 & 40 & 12.7 & 92.3 \\
\hline Max & 49.8 & 61.3 & 15.4 & 103.8 \\
\hline \multicolumn{5}{|l|}{ Pekalongan } \\
\hline Mean & $32.48 \pm 0.9$ & $21.08 \pm 3.1$ & $9.11 \pm 2.04$ & $75 \pm 8.24$ \\
\hline Min & 31.2 & 19.4 & 7.6 & 70.8 \\
\hline Max & 33.6 & 26.6 & 12.7 & 89.7 \\
\hline \multicolumn{5}{|l|}{ Pemalang } \\
\hline Mean & $38.16 \pm 6.51$ & $27 \pm 3.32$ & $9.84 \pm 1.65$ & $76 \pm 8.02$ \\
\hline Min & 28.5 & 22 & 8.3 & 67 \\
\hline Max & 48 & 33.3 & 12.9 & 90 \\
\hline \multicolumn{5}{|c|}{ Canadian sediment quality guideline } \\
\hline ERL & 81 & 34 & 46.7 & 150 \\
\hline ERM & 370 & 270 & 218 & 410 \\
\hline TEL & 52.3 & 18.7 & 30.2 & 124 \\
\hline PEL & 160 & 108 & 112 & 271 \\
\hline \multicolumn{5}{|c|}{ US EPA sediment quality guideline } \\
\hline Not polluted & $<25$ & $<25$ & $<40$ & $<90$ \\
\hline Moderately polluted & $25-75$ & $25-50$ & $40-60$ & $90-200$ \\
\hline Heavily polluted & $>75$ & $>50$ & $>60$ & $>200$ \\
\hline
\end{tabular}

\section{Enrichment factor}

The EF is generally employed to explain the contribution of metals other than those of lithogenic origin and to assess the degree of anthropogenic influence. The EFs of the metals in the sediments of the study area are displayed in ESM 7. The highest EF value was recorded for manganese in all regions (indicating considerable enrichment for Pemalang), while no enrichment of $\mathrm{Pb}$ was observed in any region. The $\mathrm{EF}$ value of $\mathrm{Zn}$ was from 1 to 2, indicating a moderate enrichment by this element. The EF value can also be used to differentiate be- tween crustal and noncrustal sources of trace metals. Metals are considered to originate from the crust when the EF is between 0.5 and 1.5 and from an anthropogenic source when the EF is more than 1.5 (Zhang and Liu 2002). The EF value for the $\mathrm{Cr}$ in Brebes was above 1.5, suggesting an anthropogenic source of $\mathrm{Cr}$ in this region, while in the other three regions, $\mathrm{Cr}$ came from natural sources. The EF values of $\mathrm{Pb}$ and $\mathrm{Cu}$ were lower than 1.5 in all studied areas, indicating that these metals originated from the crust. In contrast, Mn was considered to have originated from anthropogenic sources in all regions except Pekalongan. 


\section{Geoaccumulation index}

According to Muller (1969), the metal contamination levels were classified into seven levels: uncontaminated $\left(I_{\text {geo }} \leq 0\right)$, uncontaminated to moderately contaminated $\left(0<I_{\mathrm{geo}} \leq 1\right)$, moderately contaminated $\left(1<I_{\mathrm{geo}} \leq 2\right)$, moderately to heavily contaminated $\left(2<I_{\text {geo }} \leq 3\right)$, heavily contaminated $\left(3<I_{\text {geo }} \leq 4\right)$, heavily to extremely contaminated $\left(4<I_{\text {geo }} \leq 5\right)$, and extremely contaminated $\left(I_{\text {geo }}=5\right)$ in terms of $I_{\text {geo }}$.

As shown in Table 3, almost all metals had $I_{\text {geo }}$ index values of less than 0 , which suggested that the sediments in the study area were not polluted by these metals. There was no contamination by Mn in Pekalongan, the sediments in Brebes and Tegal were uncontaminated to moderately contaminated, and those in Pemalang were moderately contaminated.

An $I_{\text {geo }}$ value of less than 0 indicates a lithogenic origin, while a positive $I_{\text {geo }}$ index indicates the enrichment of metals of nonlithogenic origin. The results suggest that Mn was gen- erally enriched by anthropogenic sources while the other metals were of lithogenic origin.

\section{Contamination factor and pollution load index}

Based on the CF value (ESM 8), Fe and $\mathrm{Pb}$ showed a low degree of contamination in all regions and Mn contaminated the sediment in all regions (moderate degree of contamination in Brebes, Tegal, and Pekalongan and considerable degree of contamination in Pemalang). The PLI value of Pekalongan was less than 0 , indicating a low degree of contamination, while that of Brebes, Tegal, and Pekalongan indicated a mod- erate degree of contamination, with values of $1.11 \pm 0.08$. The PLI indicated a moderate degree of contamination of the study zone (Fig. 3).

\section{Potential ecological risk index}

The potential ecological risk index for metal was proposed by Hakanson (1980) to evaluate the potential ecological risk posed by the metals in sediments based on the toxicity of heavy metals and the response of the environment. ESM 9 shows the value of the ecological risk factor $\left(E^{i}\right)$ and the RI of the sediment. Generally, the highest RI value among the trace metals in the sediments was that of $\mathrm{Cu}$ followed by that of $\mathrm{Pb}$, although both still indicated low potential ecological risk.

\section{Occurrence of metals in the shrimp}

Generally, there were significant differences $(p>0.05)$ in the heavy metal concentrations (dry weight) in the whole body tissue of shrimp of different sizes. The pattern of metal

Table 3 Geoaccumulation index $\left(I_{\text {geo }}\right)$ for the metal concentrations at the 20 stations

\begin{tabular}{|c|c|c|c|c|c|c|}
\hline \multirow{2}{*}{ Region } & \multicolumn{7}{|c|}{ The geo-accumulation index (I-geo) } \\
\cline { 2 - 7 } & $\mathrm{Co}$ & $\mathrm{Cr}$ & $\mathrm{Cu}$ & $\mathrm{Mn}$ & $\mathrm{Pb}$ & $\mathrm{Zn}$ \\
\hline Brebes & $-0.76 \pm 0.03$ & $-0.73 \pm 0.19$ & $-0.24 \pm 0.19$ & $0.74 \pm 0.26$ & $-0.88 \pm 0.13$ & $-0.18 \pm 0.02$ \\
\hline Tegal & $-0.77 \pm 0.014$ & $-0.04 \pm 0.27$ & $0.45 \pm 0.027$ & $0.14 \pm 0.48$ & $-0.86 \pm 0.01$ & $-0.11 \pm 0.07$ \\
\hline Pekalongan & $-0.6 \pm 0.016$ & $-1,33 \pm 0.019$ & $-0.84 \pm 0.019$ & $-0.25 \pm 0.57$ & $-1.51 \pm 0.29$ & $-0.51 \pm 0.15$ \\
\hline Pemalang & $-0.29 \pm 0.17$ & $-0.97 \pm 0.17$ & $-0.48 \pm 0.17$ & $1.64 \pm 0.32$ & $-1.39 \pm 0.23$ & $-0.49 \pm 0.15$ \\
\hline
\end{tabular}

$\left.I_{\text {geo }} \leq 0\right)$, class 0 (uncontaminated); $\quad\left(0<I_{\text {geo }} \leq 1\right)$, class 1 (uncontaminated to moderately contaminated) 
Among the ten metals, Al presented the highest level in all regions, followed by Fe and $\mathrm{Zn}$. A similar tendency was observed in the wet and dry seasons. Wu and Yang (2011) found that Fe and $\mathrm{Zn}$ were the two most concentrated metals in the muscle tissue of wild L. vannamei, and the order of concentration was $\mathrm{Fe}>\mathrm{Zn}>\mathrm{Cu}>\mathrm{Cr}>\mathrm{Mn}$.

In the present study, the $\mathrm{Cu}$ concentration $(4.08 \pm$

$2.98 \mathrm{mg} \mathrm{kg}^{-1} \mathrm{dw}$ ) was relatively similar to that reported for the muscle tissues of L. vannamei by Lacerda et al. (2009), which ranged from 23.2 to $63.4 \mu \mathrm{g} \mathrm{g}^{-1} \mathrm{dw}$. Previously, Páez- Osuna and Ruiz-Fernández(1995)reported Cu concentrations in the muscle tissue of this species in natural populations that varied from 22.7 to $27.5 \mathrm{\mu g} \mathrm{g}^{-1} \mathrm{dw}$. The metal concentration in $L$. vannamei was compared with that of samples from dif- ferent countries as shown in Table 4.

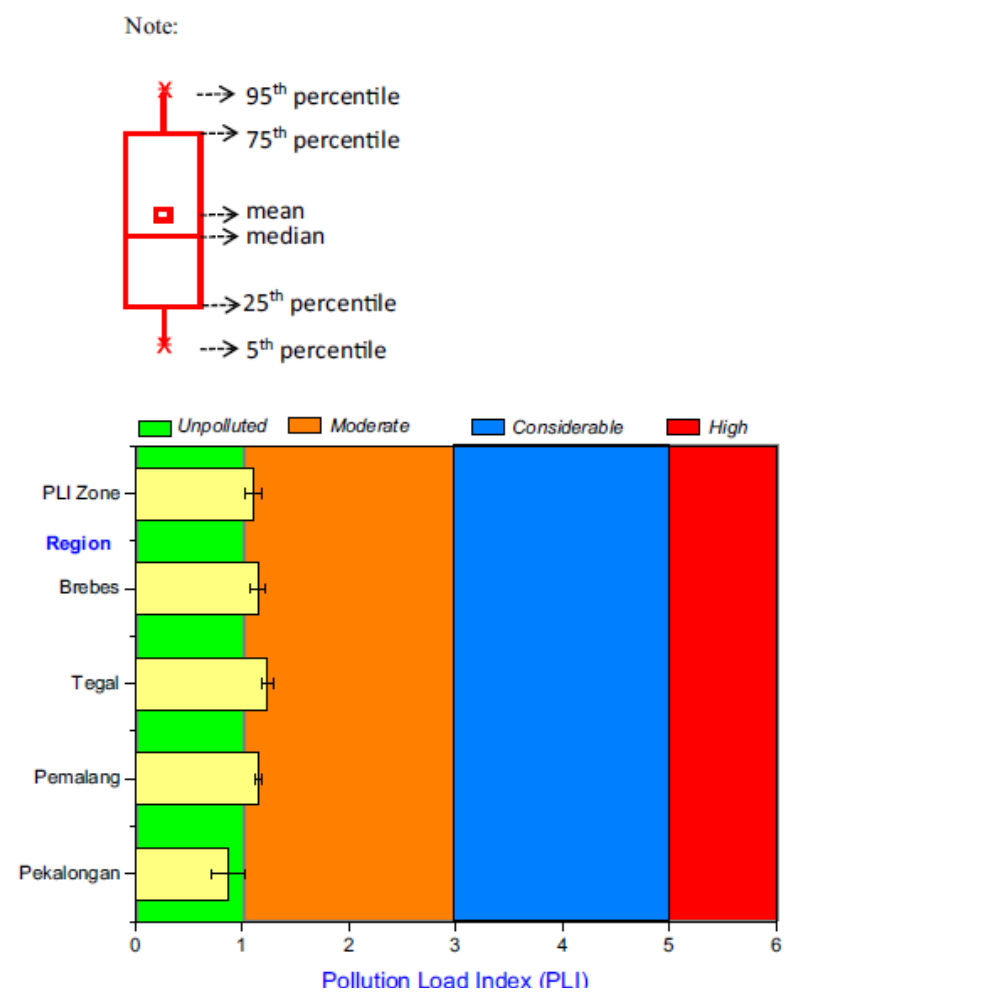

Fig. 3 Pollution load index (PLI) of the metals in the sediments of the studied area

$\mathrm{Cu}, \mathrm{Fe}, \mathrm{Mn}$, and $\mathrm{Zn}$ are essential oligo-elements for L. vannamei (Frías-Espericueta et al. 2009), although high concentrations may affect metabolism. Dietary $\mathrm{Cu}$ impacts the composition of gut microbiota and subsequently affects the immune response and growth. For instance, the dietary $\mathrm{Cu}$ required to meet the growth and immune functions of $L$. vannamei has been estimated at approximately $30 \mathrm{mg} \mathrm{kg}^{-1}$ (Ayisi et al. 2017). At the higher level of accumulation in the shrimp muscle tended to be in the same decreasing order in Tegal and Pekalongan, in which $\mathrm{Al}$ and $\mathrm{Fe}$ were the most accumulated and Co was the least accumulated. Wu and Chen (2005) showed that Cd mostly accumulated in the hepatopancreas followed by the gills and muscle. Overall, the descending order of the concentrations of the metals analyzed in this study during the wet season was as follows:

Brebes: $\mathrm{Al}>\mathrm{Zn}>\mathrm{Fe}>\mathrm{Cu}>\mathrm{Mn}>\mathrm{Cr}>\mathrm{Hg}$

Tegal: $\mathrm{Al}>\mathrm{Fe}>\mathrm{Zn}>\mathrm{Cu}>\mathrm{Mn}>\mathrm{Cr}>\mathrm{Pb}>\mathrm{Hg}>\mathrm{Cd}>\mathrm{Co}$ Pekalongan: $\mathrm{Al}>\mathrm{Fe}>\mathrm{Zn}>\mathrm{Cu}>\mathrm{Mn}>\mathrm{Cr}>\mathrm{Pb}>\mathrm{Hg}>\mathrm{Co}>\mathrm{Cd}$

Pemalang: $\mathrm{Al}>\mathrm{Fe}>\mathrm{Zn}>\mathrm{Cu}>\mathrm{Mn}>\mathrm{Cr}>\mathrm{Hg}>\mathrm{Pb}>\mathrm{Cd}>\mathrm{Co}$

A similar tendency was observed for metal accumulation during the dry season as follows:

Brebes: $\mathrm{Al}>\mathrm{Zn}>\mathrm{Fe}>\mathrm{Cu}>\mathrm{Mn}>\mathrm{Cr}>\mathrm{Hg}>\mathrm{Cd}>\mathrm{Co}>\mathrm{Pb}$ Tegal: $\mathrm{Al}>\mathrm{Fe}>\mathrm{Zn}>\mathrm{Cu}>\mathrm{Mn}>\mathrm{Pb}>\mathrm{Cr}>\mathrm{Hg}>\mathrm{Co}>\mathrm{Cd}$

Pekalongan: $\mathrm{Al}>\mathrm{Fe}>\mathrm{Zn}>\mathrm{Cu}>\mathrm{Mn}>\mathrm{Pb}>\mathrm{Cr}>\mathrm{Hg}>\mathrm{Co}>\mathrm{Cd}$

Pemalang: $\mathrm{Al}>\mathrm{Fe}>\mathrm{Mn}>\mathrm{Zn}>\mathrm{Cu}>\mathrm{Cr}>\mathrm{Hg}>\mathrm{Pb}>\mathrm{Cd}>\mathrm{Co}$

Generally, the metal concentrations in the shrimp in the dry season were slightly higher than those in the wet season as shown in Pekalongan (ESM 10). 
$64 \mathrm{mg} \mathrm{kg}^{-1}$, the survival of L. vannamei has been shown to be slightly depressed as reported by Davis et al. (1993).

The average concentrations $\left(\mu \mathrm{g} \mathrm{g}^{-1} \mathrm{dw}\right)$ of $\mathrm{Cu}$ in the stud- ied shrimp muscle in the Brebes, Tegal, Pekalongan, and Pemalang regions were $26.9 \pm 8.72,27.3 \pm 2.6,25.6 \pm 4.8$, and $36.5 \pm 5.3$ during the wet season, respectively, and 42.6 $\pm 2.6,37.3 \pm 6.9,31.1 \pm 5.05$, and $31.6 \pm 6.5$ during the dry season, respectively.

Wu and Chen (2004) found that $\mathrm{Zn}$ affects the gill function of this shrimp species. Frías-Espericueta et al. (2009) studied the effect of exposure to a mixture of Cd-Zn on L. vannamei and showed an antagonistic effect on this species, which aligned with the results of Barata et al. (2006), who empha- sized that there is a high probability of competition for protein binding sites because $\mathrm{Zn}, \mathrm{Cu}$, and $\mathrm{Cd}$ are inducers of metallo- thionein synthesis. Thus, the combined effects of $\mathrm{Cd}$ and $\mathrm{Zn}$ may be expected to be antagonistic.

Concerning $\mathrm{Hg}$, the average concentrations $\left(\mu \mathrm{g} \mathrm{g}^{-1} \mathrm{dw}\right.$ ) of $\mathrm{Hg}$ in shrimp ranged from $0.16 \pm 0.04$ (Pemalang) to $1.35 \pm 0.89$ (Brebes). The $\mathrm{Hg}$ source may have originated from the drainage basin (industrial, agricultural, and domestic effluents), where $\mathrm{Hg}$ is trapped and accumulates in a mangrove tidal creek, which may be a potential source of contamination in adjacent aquaculture sites (Costa et al. 2013), or the source may have originated from the shrimp farms because of the large amounts of feed applied during breeding. Lacerda et al. (2011) estimated an EF from intensive shrimp farming of $83.5 \mathrm{mg} \mathrm{Hg} \mathrm{ha}^{-1}$ cycle $^{-1}$, which is comparable to the $\mathrm{Hg}$ emissions from urban wastewaters $\left(200 \mathrm{mg} \mathrm{ha}^{-1}\right)$ and solid waste disposal $\left(400 \mathrm{mg} \mathrm{ha}^{-1}\right.$ year $\left.{ }^{-1}\right)$ from cities located in the NE Brazil. 
Table 4 Comparison of the mean concentrations $\left(\mathrm{mg} \mathrm{kg}^{-1} \mathrm{dw}\right.$ ) of trace metals reported for shrimp worldwide (muscle)

\begin{tabular}{|c|c|c|c|c|c|c|c|c|c|c|c|c|c|}
\hline \multicolumn{14}{|l|}{ Location } \\
\hline Mexico & L. vannamei & & $0.77 \pm 0.01$ & $1.18 \pm 0.5$ & $27.5 \pm 2.4$ & $0.85 \pm 0.14$ & $53.9 \pm 9-0$ & $4-54 \pm 3.84$ & & $70.4 \pm 4.9$ & & $0.81 \pm 0.10$ & \\
\hline Mexico & L. vannamei & & & & & & & & & & $0.194 \pm 0.509$ & & \\
\hline Mexico & L. vannamei & & & & $19.2 \pm 0.8$ & & $37 \pm 9$ & $3.0 \pm 1.7$ & & $56 \pm 6$ & & & \\
\hline India & $\begin{array}{l}\text { Penaeus } \\
\quad \text { monodon }\end{array}$ & & & & $77 \pm 11$ & & $297 \pm 8$ & $15.2 \pm 3.3$ & $0.147 \pm 0.10$ & $058 \pm 21$ & & & \\
\hline Malaysia & L. vannamei & & $0.1 \pm 0.04$ & $1.5 \pm 0.20$ & $51.3 \pm 10.12$ & $3.8 \pm 0.13$ & & $31.7 \pm 1.77$ & 3 & $72.4 \pm 0.14$ & & $2.2 \pm 0.35$ & $4.5 \pm 0.04$ \\
\hline Bangladesh & $\begin{array}{l}\text { Parapenaeopsis } \\
\text { sculptilis }\end{array}$ & & $0.713 \pm 0.06$ & & $5.049 \pm 0.07$ & $7<0.08$ & $18.713 \pm 2.63$ & $<0.2$ & $0.69 \pm 1.56$ & $13.5 \pm 0.43$ & $<0.03$ & & \\
\hline $\begin{array}{l}\text { NW } \\
\text { Mexico }\end{array}$ & L. vannamei & & & & & & & & & & $0.20 \pm 0.01$ & & \\
\hline Malaysia & $\begin{array}{l}\text { Penaeus } \\
\text { vannamei }\end{array}$ & & $0.001 \pm 0.001$ & & $6.806 \pm 0.33$ & $0.023 \pm 0.015$ & & & $0.108 \pm 0.03$ & $\begin{array}{ll}3 & 12.67 \pm 0.2\end{array}$ & $0.04 \pm 0.003$ & & \\
\hline China & P. vannamei & & n.d. & n.d. & $24.26 \pm 8.36$ & $620.86 \pm 5.27$ & $61.35 \pm 30.76$ & $65.33 \pm 2.50$ & n.d. & $171.6 \pm 118.7$ & & & \\
\hline China & Shrimp & & $0.001-0.32$ & & $2.28-28.13$ & $0.18-2.14$ & & & & $9.58-19.16$ & $0.001-0.018$ & $0.001-0.25$ & \\
\hline California & L. vannamei & & $0.14 \pm 0.02$ & & $18.4 \pm 2.99$ & & & & $0.56 \pm 0.04$ & $13.0 \pm 1.28$ & & & \\
\hline Indonesia & L. vannamei & $200.82 \pm 171.7$ & $0.09 \pm 0.06$ & $0.12 \pm 0.1$ & $4.08 \pm 2.98$ & $32.48 \pm 8.7$ & $133.58 \pm 86.48$ & $831.93 \pm 50.37$ & $7.49 \pm 8.96$ & $67.49 \pm 5.52$ & $0.36 \pm 0.43$ & & \\
\hline
\end{tabular}

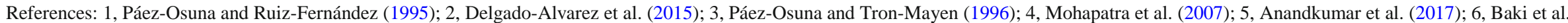
(2018); 7, Ruelas-Inzunza and Páez-Osuna (2004); 8, Mok et al. (2012); 9, Wu and Yang (2011); 10, Liu et al. (2019); 11, Jara-Marini et al. (2009) 


\section{Estimated daily intake}

To evaluate whether the metal levels found in the shrimp samples were safe for consumers, a comparison was per-formed with their tolerable intake. The calculated daily intake of the metals through the consumption of shrimp was below the acceptable daily intake suggested by the joint FAO/WHO Expert Committee on Food Additives and ATSDR for almost all samples with the exception of Cr during the dry season in Tegal and Pemalang (ESM 11). Based on this result, it can be recommended that the consumption of average amounts of the analyzed shrimps does not pose any health risk for shrimp consumers.

Based on the Indonesia Statistics Center database, the con- sumption rate of fresh fish and fish products in Central Java was $20.67 \mathrm{~g}$ person ${ }^{-1}$ day $^{-1}$ (BPS 2016). By considering the mean body weight of Asian adults as $57.7 \mathrm{~kg}$ (Walpole et al. 2012), the daily intake of metals was calculated. A linear relationship is observed based on the weight applied to esti- mate the EDI and THQ values in Taiwan by Ju et al. (2017), which was $57.3 \mathrm{~kg}$ for female adults aged 19-65 years old.

\section{Target hazard quotient and hazard index}

The THQ and HI were calculated to assess the potential risks due to metals from the consumption of shrimp raised in aquaculture ponds. In both the wet season and dry season, the THQ was less than 1, indicating that there was no obvious health risk from the intake of the individual metals. The hazard index value of below 1 also suggested no potential adverse effect from the combined metals from shrimp consumption through- out the year. However, the HI value tended to be higher in the dry season than the wet season except for Brebes (ESM 12). Mercury had a significant influence on the HI value in this region.

$\mathrm{Pb}$ had the highest THQ value during the dry season in Pekalongan, followed by $\mathrm{Cr}$. It is well known that Pekalongan is one of the batik industrial cities in Indonesia (Rukayah et al. 2015) and that batik production has become the dominant activity among the local inhabitants (Hadiyanto et al. 2018). This industry produces wastewater that contains heavy metals, such as lead, chromium, and copper as a result of the production process (Puspita et al. 2011; Rashidi et al. 2012; Setiyono and Gustaman 2017). Synthetic dyes contain- ing $\mathrm{Pb}$ and $\mathrm{Cr}$ are widely used during the coloring process of batiks to increase the bonding strength between the dyes and fabrics (Hadiyanto et al. 2018).

Madusari et al. (2016) detected the toxic metals $\mathrm{Pb}$ and $\mathrm{Cd}$ in the water column and Chanos chanos from a pond in this region. It was assumed that those metals came from the riverine system as the water source for the aquaculture system. Anandriyo Suryo and Indah (2013) reported that the rivers in Pekalongan have been polluted. Because of the limitation of actual wastewater treatment plant facilities, they estimated that the wastewater in Pekalongan that cannot be treated amounted to $3600 \mathrm{~m}^{3}$ per day from 632 home batik industries in 2011. As the result, wastewater entered into the riverine system. Furthermore, the local societies and batik entrepreneurs lack an awareness of the riverine environments, which leads to worse river pollution.

\section{Target cancer risk}

Chromium in the white-legged shrimp tissue is the primary risk for human health (Wu and Yang 2011). Cr showed a moderate cancer risk $\left(\mathrm{TR}=10^{-4}\right)$ for the exposed population in all regions, in both the wet season and dry season (ESM 13). While $\mathrm{Pb}$ indicated a low cancer risk during the wet season in all regions, the risk increased from low to mod- erate during the dry season in Tegal and Pekalongan as shown by the value of $10^{-5}$ (between $10^{-6}$ and $10^{-4}$ ) stipulated by the New York State Department of Health (NYSDOH 2007).

\section{Predominant metals in different environmental matrices}

The PCA results correlating the extent of the metals in water are presented in Fig. 4. The cumulative variance contribution of PC1 was 44\%. PC1 had high loadings and strong correla- tions with Al and Fe $(R=0.79)$ (Fig. 4a). The Brebes, Pekalongan, and Pemalang districts were correlated with Al and Fe concentrations (ESM 14a). This result confirmed the important contribution of the riverine system to the major metal contaminants rather than anthropogenic inputs, such as the precipitation of aerosol particles released by industrial ac- tivities (Ye et al. 2017) and the use of fertilizer in agriculture in the upstream areas (Comero et al. 2014). PC2 accounted for 22.1\% of the variations and had high loadings of $\mathrm{Zn}$ and Mn, although a low correlation was observed between them $(R=0.12)$ (Fig. 4a). The most prominent metals at the Tegal district stations were $\mathrm{Cu}$ and $\mathrm{Cd}$, which were moderately correlated $(R=0.46)$. In this district, which has the densest suburban population, the presence of $\mathrm{Cu}$ and $\mathrm{Cd}$ can be associated with industrial activities, i.e., fishing, farming, and shipyard activ- ity (De Witte et al. 2016). 
In the sediment, we observed that PC1 accounted for $44.1 \%$ of the variance and had high loadings on $\mathrm{Cu}$ and $\mathrm{Cr}$ as well as $\mathrm{Pb}$ and $\mathrm{Zn}$, while PC2 elucidated $18 \%$ of the total variance and had a high loading of Mn (Fig. 4). The occur- rence of $\mathrm{Zn}$ was correlated with $\mathrm{Cu}$ and $\mathrm{Pb}$ (both $R=0.73)$, and $\mathrm{Cr}$ was correlated with $\mathrm{Al}(R=0.73)$ and $\mathrm{Pb}(R=0.65)(\mathrm{ESM} 14 \mathrm{~b})$. $\mathrm{Zn}$ and $\mathrm{Cr}$ were correlated, with $R=0.60$. Al showed a strong correlation with $\mathrm{Pb}(R=0.55)$ and $\mathrm{Zn}(R=0.50)$, while Fe and Mn were also strongly correlated with Co $(R=0.56)($ ESM 14b). Figure 4 b shows that the sediment from Pekalongan and Tegal was characterized by high

concentrations of $\mathrm{Cu}, \mathrm{Cr}, \mathrm{Pb}$, and $\mathrm{Zn}$. In fact, Pekalongan is the area known for batik textiles (Rukayah et al. 2015), which are processed with $\mathrm{Cr}$ dye; thus, $\mathrm{Cr}$ ends up as a byproduct and an environmental contaminant in the riverine system. As shown in Fig. 4 a, b, and c, Al, Cd, Co, and Fe were associated with the second component, which may indicate that the sources of those metals in the sediment were similar and likely from natural sources. This finding was confirmed by the use of several indexes, with the EF, $I_{\text {geo }}$, and $\mathrm{CF}$ showing that the $\mathrm{Al}, \mathrm{Cd}, \mathrm{Co}$, and Fe concentrations in the sediment at some sampling sites were lower than the background concentrations.

Concerning the shrimp, PC1 accounted for $27.86 \%$ of the total variance and PC2 accounted for $24.7 \%$. Figure $4 \mathrm{c}$ shows that the $\mathrm{Al}$ concentration was highly correlated with the Fe $(R=0.94)$, Mn $(R=0.64)$, and $\mathrm{Zn}(R=0.54)$ concentrations. The points in the figure represent the soil samples $(n=40)$. Many points were close, which indicates that these samples had less variability but were adequately discriminated. Figure $4 \mathrm{c}$ also shows that the Cd concentrations had the same higher magnitude as the eigenvalues of $\mathrm{Cu}, \mathrm{Co}$, and $\mathrm{Zn}$, which formed a group that was not attributed to a specific site. Figure $4 \mathrm{c}$ and ESM 14c show that the Fe concentrations were highly correlated with the $\mathrm{Mn}(R=0.66), \mathrm{Pb}(R=0.54)$, and $\mathrm{Zn}(R=0.53)$ concentrations, whereas the Mn and Hg concen- trations were not correlated despite sharing the same eigen- values. ESM 12 shows that $\mathrm{Pb}$ and $\mathrm{Cr}$ were the most influen- tial to the THQ, especially in Tegal.

In the present study, the metal environmental status of

L. vannamei in aquaculture systems in Indonesia has been described for the first time. This study used a comprehensive pollution index and demonstrated that aquaculture pond water is probably contaminated by Mn and $\mathrm{Zn}$ from natural sources. Regarding the sediment, our findings from various indexes ( $I_{\text {geo }}, \mathrm{CF}$, and PLI) showed that the sediments were not polluted by the studied metals and were considered to present a low ecological risk. Despite the occurrence of many heavy metals in shrimp, $\mathrm{Zn}$ remained a source of concern because it was found in excess in the L. vannamei muscle. 
Fig. 4 Principal component analysis of the metals in a water, $b$ sediment, and c shrimp
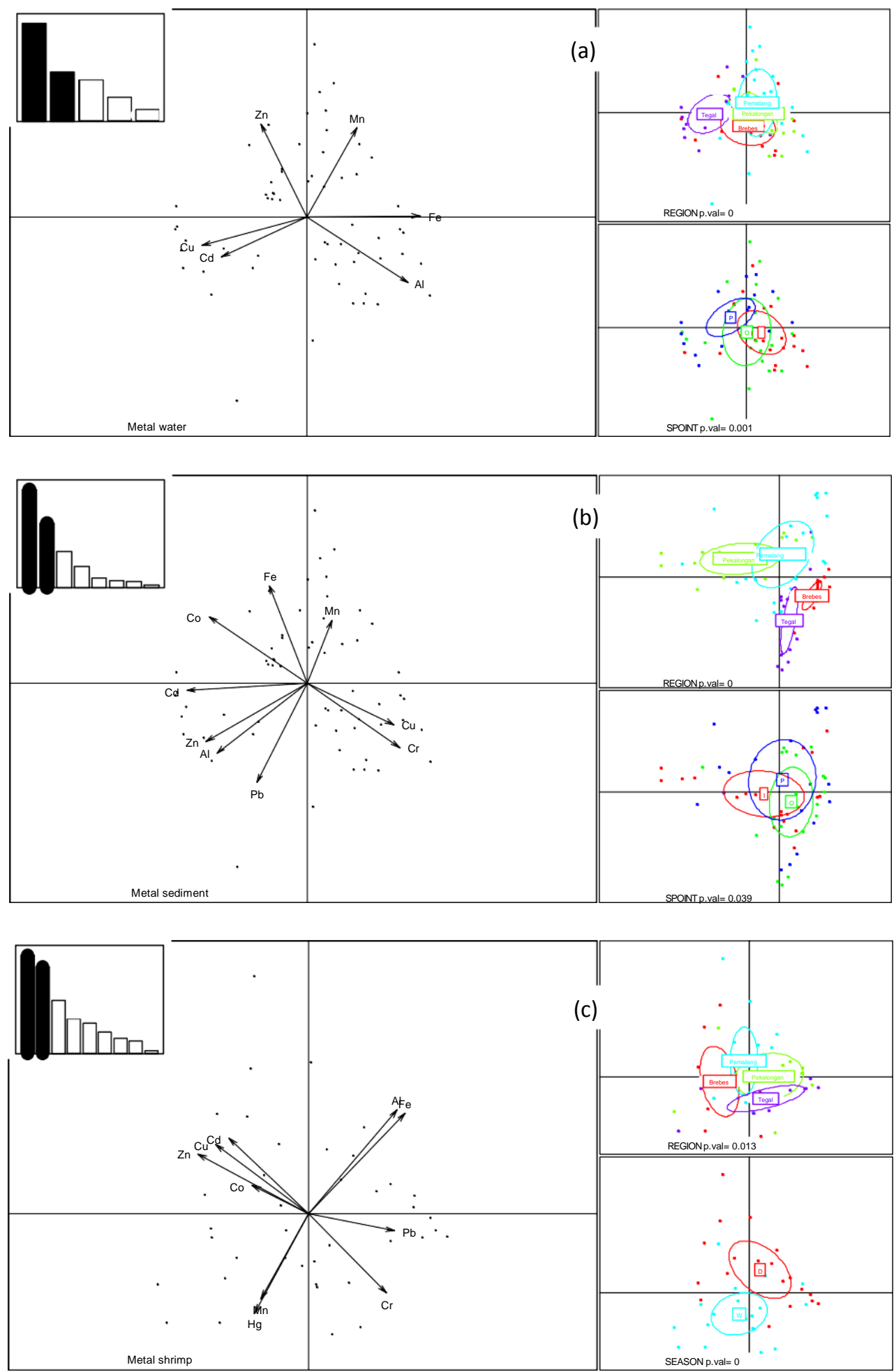


\section{Conclusions}

Here, we investigated the ecological and human health risks of heavy metals in the water and sediment in aquaculture environments. The results showed that the occurrence of heavy metals in water was dependent on the site. The results suggested that riverine systems contributed to higher concentra- tions of Fe and $\mathrm{Mn}$. The nonessential element $\mathrm{Cd}$ was observed in the shrimp ponds as a trace element in all regions, with the highest level found in Pekalongan $(3.15 \pm$

$0.33 \mu \mathrm{g} \mathrm{L}^{-1}$ ). From the water assessment, the greatest poten- tial ecological hazard was Mn based on the $P_{n}$ value. Concerning the sediment, $\mathrm{Cr}, \mathrm{Cu}, \mathrm{Zn}, \mathrm{Co}$, and $\mathrm{Pb}$ showed similar spatial variation trends with decreasing concentrations. Their high-value area was located in Brebes, and the lowest value occurred in Pekalongan. The risk assessment for sedi- ment using the SQG results suggested that the ecological risk of heavy metals at the studied sites was low. However, the EF, $I_{\text {geo }}, \mathrm{CF}$, and PLI values for $\mathrm{Mn}$ showed a medium-high envi- ronmental risk. In shrimp, the accumulation of $\mathrm{Al}, \mathrm{Fe}, \mathrm{Zn}, \mathrm{Cu}$, and $\mathrm{Mn}$ showed similar trends at all stations and low values of $\mathrm{Hg}, \mathrm{Pb}, \mathrm{Cd}$, and $\mathrm{Co}$ were observed. The findings of this re- search also revealed that the lack of risk associated with con- sumption if we assumed that protein daily intake per capita was approximately $20 \mathrm{~g}_{\text {person }}{ }^{-1} \mathrm{day}^{-1}$ for all studied heavy metals. Furthermore, the THQ and HI were higher in the dry season, and our findings demonstrated that $\mathrm{Pb}$ and $\mathrm{Cr}$ influ- enced the THQ while $\mathrm{Hg}$ significantly influenced the HI val- ue. This research provided an adequate overview of the heavy metal contamination in different environmental matrices, al- though further study is necessary to design the conceptual framework model for heavy metal contamination in an aqua- culture field to better mitigate the hazards and risks in sustain- able aquaculture.

\footnotetext{
Acknowledgments The authors thank Elodie Vermeille, Wulandari Sarasati, Jamaludin, Rizqy Firmansyah, Helmi Mubarak, and Jessica for their support and help during the sampling campaign and during sample processing in the laboratory. Finally, we also thank the reviewers for their helpful comments and suggestions.
}

Funding information This study received financial support from the Indonesian Endowment Fund for Education (LPDP), the Ministry of Finance, the Directorate General of Higher Education (DIKTI), and the Ministry of Research, Technology and Higher Education of the Republic of Indonesia, provided through the framework of the BUDI-LN program and a doctoral research grant. 


\section{References}

Abrahim GMS, Parker RJ (2008) Assessment of heavy metal enrichment factors and the degree of contamination in marine sediments from Tamaki Estuary, Auckland, New Zealand. Environ Monit Assess 136:227-238

Ahmed MK, Baki MA, Islam MS, Kundu GK, Habibullah-Al-Mamun M, Sarkar SK, Hossain MM (2015) Human health risk assessment of heavy metals in tropical fish and shellfish collected from the river Buriganga, Bangladesh. Environ Sci Pollut Res 22:15880-15890

Ahmed MM, Doumenq P, Awaleh MO, Syakti AD, Asia L, Chiron S (2017) Levels and sources of heavy metals and PAHs in sediment of Djibouti-city (Republic of Djibouti). Mar Pollut Bull 120:340-346 Anandkumar A, Nagarajan R, Prabakaran K, Rajaram R (2017) Trace metal dynamics and risk assessment in the commercially important marine shrimp species collected from the Miri coast, Sarawak, East Malaysia. Reg Stud Mar Sci 16:79-88

Anandkumar A, Nagarajan R, Prabakaran K, Bing CH, Rajaram R(2018) Human health risk assessment and bioaccumulation of trace metals in fish species collected from the Miri coast, Sarawak, Borneo. Mar Pollut Bull 133:655-663

Anandriyo Suryo M, Indah S (2013) Menuju Pengelolaan Sungai Bersih di Kawasan Industri Batik yang Padat Limbah Cair (Studi Empiris: Watershed Sungai Pekalongan di Kota Pekalongan). Diponegoro J Econ 2:130-141

Apriliani MF, Widiyanto (2018) Influence of characteristics of entrepre- neurs, capital and labor on the success of batik industry (ind.). Econ EducAna J 7:761-776

Asare-Donkor NK, Ofosu JO, Adimado AA (2018)Hydrochemical char- acteristics of surface water and ecological risk assessment of sedi- ments from settlements within the Birim River basin in Ghana. Environ Syst Res 7:9

Ayisi CL, Hua X, Apraku A, Afriyie G, Kyei BA (2017) Recent studies toward the development of practical diets for shrimp and their nu- tritional requirements. HAYATI J Biosci24:109-117

Baki MA, Hossain MM, Akter J, Quraishi SB, Haque Shojib MF, Atique Ullah AKM, Khan MF (2018) Concentration of heavy metals in seafood (fishes, shrimp, lobster and crabs) and human health assess- ment in Saint Martin Island, Bangladesh. Ecotoxicol Environ Saf 159:153-163

Barata C, Baird DJ, Nogueira AJA, Soares AMVM, Riva MC (2006) Toxicity of binary mixtures of metals and pyrethroid insecticides to Daphnia magna Straus. Implications for multi-substance risks assessment. Aquat Toxicol 78:1-14

Bayuaji G, Damayanti A, Handayani T (2018) Environmental quality of shrimp ponds in the coastal region of Brebes Regency. The 3rd

International Conference on Energy, Environmental and Information System (ICENIS 2018). EDP Sciences, 73

Boyd CE (2009) Trace metals toxic at high concentrations. Global Aquaculture Advocate 12:24-26

Boyd CE, Massaut L (1999) Risks associated with the use of chemicals in pond aquaculture. Aquac Eng 20:113-132

BPS (2016) Consumption expenditure of population of Indonesia by province - based on the March 2016 Susenas. Statistics Indonesia, Jakarta

BPS (2018a) Brebes Regency in figures 2018. BPS-Statistics of Brebes Regency, Brebes

BPS (2018b) Pekalongan municipality in figures 2018. BPS-Statistics of Pekalongan Municipality, Pekalongan

BPS (2018c) Pemalang in figures. BPS-StatisticsofPemalangRegency, Pemalang

BPS (2018d) Tegal Regency in figures. BPS Statistics of Tegal Regency, Tegal

Brady JP, Ayoko GA, Martens WN, Goonetilleke A(2015) Development of a hybrid pollution index for heavy metals in marine and estuarine sediments. Environ Monit Assess 187:306

Brzóska MM, Moniuszko-Jakoniuk J (2001) Interactions between cad- mium and zinc in the organism. Food Chem Toxicol 39:967-980

CCME (2007) Canadian environmental quality guidelines Chapter 6: Canadian sediment quality guidelines for the protection of aquatic life Canadian Council of Ministers of the Environment

Cheng B, Liu Y, Yan H, Song Y, Li X (2014) Effect of copper on the growth of shrimps Litopenaeus vannamei: water parameters and copper budget in a recirculating system. Chin J Oceanol Limnol 32:1092-1104

Comero S, Vaccaro S, Locoro G, De Capitani L, Gawlik BM (2014) Characterization of the Danube River sediments using the PMF multivariate approach. Chemosphere 95:329-335

Costa BGB, Soares TM, Torres RF, Lacerda LD (2013) Mercury distri- bution in a mangrove tidal creek affected by intensive shrimp farm- ing. Bull Environ Contam Toxicol 90:537-541

Dadzie AA, Yuan L, Xing S, Liu X, Zhou X (2020) Survey and assess- ment of metals distribution in the overlying water of the representa- tive lake and rivers in Zhenjiang, China. SN Appl Sci 2:776

Davis DA, Lawrence AL, Gatlin III, D. (1993) Dietary copper require- ment of Penaeus vannamei. Nippon Suisan Gakkaishi 59:117-122 DelgadoAlvarez CG, Ruelas-Inzunza J, Osuna-López JI, Voltolina D, Frías-Espericueta MG(2015) Mercury content and their risk assessment in farmed shrimp Litopenaeus vannamei from NW Mexico.

Chemosphere 119:1015-1020

De Witte B, Ruttens A, Ampe B, Waegeneers N, Gauquie J, Devriese L, Cooreman K, Parmentier K (2016) Chemical analyses of dredged spoil disposal sites at the Belgian part of the North Sea. Chemosphere 156:172-180

Dickinson WW, Dunbar GB, McLeod H (1996) Heavy metal history from cores in Wellington arbour, New Zealand. Environ Geol 27: 59-69

Fakhri Y, Mohseni-Bandpei A, Oliveri Conti G, Ferrante M, Cristaldi A, Jeihooni AK, Karimi Dehkordi M, Alinejad A, Rasoulzadeh H, Mohseni SM, Sarkhosh M, Keramati H, Moradi B, Amanidaz N, Baninameh Z (2018) Systematic review and health risk assessment of arsenic and lead in the fished shrimps from the Persian gulf. Food Chem Toxicol 113:278-286

FAO (2018a) FAO yearbook. Fishery and aquaculture statistics 2016, Rome

FAO (2018b) The State of World Fisheries and Aquaculture 2018 - meet- ing the sustainable development goals, Rome, Licence: CCBY-NC- SA 3.0 IGO

Finley BL, Monnot AD, Paustenbach DJ, Gaffney SH (2012) Derivation of a chronic oral reference dose for cobalt. Regul Toxicol Pharmacol 64:491503

Frías-Espericueta MG, abad-rosales S, Nevarez-Velazquez AC, Osuna- Lopez I, Paez-Osuna F, Lozano-Olvera R, Voltolina D (2008a) Histological effects of a combination of heavy metals on Pacific white shrimp Litopenaeus vannamei juveniles. Aquat Toxicol 89: 152-157

Frías-Espericueta MG, Castro-Longoria R, Barrón-Gallardo GJ, Osuna- López JI, Abad-Rosales SM, Páez-Osuna F, Voltolina D (2008b) 
Histological changes and survival of Litopenaeus vannamei juve- niles with differentcopperconcentrations. Aquaculture278:97-100 FríasEspericueta MG, Voltolina D, Osuna-López I, Izaguirre-Fierro G (2009) Toxicity of metal mixtures to the Pacific white shrimp Litopenaeus vannamei postlarvae. Mar Environ Res 68:223-226 Ganugapenta S, Nadimikeri J, Chinnapolla SRRB, Ballari L, Madiga R, Nirmala K, Tella LP (2018) Assessment of heavy metal pollution from the sediment of Tupilipalem coast, southeast coast of India. Int J Sediment Res 33:294-302

Garcia-Hernandez J, Ortega-Velez MI, Contreras-Paniagua AD, Aguilera-MarquezD, Leyva-Garcia G, Torre J(2018)Mercury con- centrations in seafood and the associated risk in women with high fish consumption from coastal villages of Sonora, Mexico. Food Chem Toxicol 120:367-377 Gargouri D, Gzam M, Kharroubi A, Jedoui Y (2018) Use of sediment quality indicators for heavy metals contamination and ecological risk assessment in urbanized coastal zones. Environ Earth Sci 77

Gu YG, Li QS, Fang JH, He BY, Fu HB, Tong ZJ (2014) Identification of heavy metal sources in the reclaimed farmland soils of the pearl river estuary in China using a multivariate geostatistical approach. Ecotoxicol Environ Saf 105:7-12

Hadiyanto, Budiyanto S, Anies, Purnaweni H, Rya Sunoko H, Sudarno, Maryono (2018) Environmental analysis of the impacts of batik waste water polution on the quality of dug well water in the batik industrial center of Jenggot Pekalongan City. E3S Web of Conferences, 31

Hakanson L (1980) An ecological risk index for aquatic pollution control.a sedimentological approach. Water Res 14:975-1001

Hartini E (2011) Kadar plumbum (pb) dalam umbi bawang merah di kecamatan kersana kabupaten brebes. Jurnal Visikes 10:69-75

Ismanto H (2019) The association of lead levels and malondialdehyde levels of pregnant woman in coastal area of Brebes District. Media Kesehatan Masyarakat Indonesia 18

Jara-Marini ME, Soto-Jiménez MF, Páez-Osuna F (2009) Trophic rela- tionships and transference of cadmium, copper, lead and zinc in a subtropical coastal lagoon food web from SE Gulf of California. Chemosphere 77:1366-1373

Jonathan MP, Munoz-Sevilla NP, Gongora-Gomez AM, Luna Varela RG, Sujitha SB, Escobedo-Urias DC, Rodriguez-Espinosa PF, Campos Villegas LE (2017) Bioaccumulation of trace metals in farmed pacific oysters Crassostrea gigas from SW Gulf of California coast, Mexico. Chemosphere 187:311-319

Ju Y-R, Chen C-W, Chen C-F, Chuang X-Y, Dong C-D (2017) Assessment of heavy metals in aquaculture fishes collected from southwest coast of Taiwan and human consumption risk. Int Biodeterior Biodegradation 124:314-325

Kabir MI, Lee H, Kim G, Jun T (2011) Correlation assessment and monitoring of the potential pollutants in the surface sediments of Pyeongchang River, Korea. Int J Sediment Res 26:152-162

Katya K, Lee S, Yun H, Dagoberto S, Browdy CL, Vazquez-Anon M, Bai SC (2016) Efficacy of inorganic and chelated trace minerals (Cu, Zn and $\mathrm{Mn}$ ) premix sources in Pacific white shrimp, Litopenaeus vannamei (Boone) fed plant protein based diets. Aquaculture 459:117-123 Keshavarzi B, Hassanaghaei M, Moore F, Rastegari Mehr M, Soltanian S, Lahijanzadeh AR, Sorooshian A (2018) Heavy metal contamina- tion and health risk assessment in three commercial fish species in the Persian Gulf. Mar Pollut Bull 129:245-252

KKP (2017) Laporan Tahunan Kementerian Kelautan dan Perikanan 2016. Kementerian Kelautan dan Perikanan RI, Jakarta

Kowalska JB, Mazurek R, Gąsiorek M, Zaleski T (2018) Pollution indi- ces as useful tools for the comprehensive evaluation of the degree of soil contamination-a review. Environ Geochem Health 40:2395-

2420

Lacerda LD, Santos JA, Madrid RM (2006) Copper emission factors fromintensive shrimp aquaculture. Mar Pollut Bull 52:1823-1826 Lacerda L, Santos J, Lopes D (2009) Fate of copper in intensive shrimp farms: bioaccumulation and deposition in pond sediments. Braz J

Biol 69:851-858

Lacerda LD, Soares TM, Costa BGB, Godoy MDP (2011) Mercury emission factors from intensive shrimp aquaculture and their relative importance to the Jaguaribe River estuary, NE Brazil. Bull Environ Contam Toxicol 87:657-661

León-Cañedo JA, Alarcón-Silvas SG, Fierro-Sañudo JF, Mariscal- Lagarda MM, Díaz-Valdés T, Páez-Osuna F (2017) Assessment of environmental loads of cu and $\mathrm{Zn}$ from intensive inland shrimp aquaculture. Environ Monit Assess 189:69

Lin S, Lin X, Yang Y, Li F, Luo L (2013) Comparison of chelated zinc and zinc sulfate as zinc sources for growth and immune response of shrimp (Litopenaeus vannamei). Aquaculture 406-407:79-84

Liu S, Zhang Y, Bi S, Zhang X, Li X, Lin M, Hu G (2015) Heavy metals distributionandenvironmental quality assessment for sediments off the southern coast of the Shandong Peninsula, China. Mar Pollut Bull 100:483-488

Liu Q, Liao Y, Shou L (2018) Concentration and potential health risk of heavy metals in seafoods collected from Sanmen Bay and its adja- cent areas, China. Mar Pollut Bull 131:356-364

Liu Q, Xu X, Zeng J, Shi X, Liao Y, Du P, Tang Y, Huang W, Chen Q, Shou L (2019) Heavy metal concentrations in commercial marine organisms from Xiangshan Bay, China, and the potential health risks. Mar Pollut Bull 141:215-226

Lizárraga-Mendiola L, Duran M-D-C, González-Sandoval M-D-R (2008) Environmental assessment of an active tailings pile in the state of Mexico (Central Mexico). Res J Environ Sci 2:197-208

Lu X, Wang L, Lei K, Huang J, Zhai Y (2009) Contamination assessment of copper, lead, zinc, manganese and nickel in street dust of Baoji, NW China. J Hazard Mater 161:1058-1062

Madusari,BD, Pranggono H, Linayati (2016) Analisis Kandungan Timbal (Pb), Cadmium (Cd) pada Air dan Ikan Bandeng (Chanos chanos) di Tambak Kota dan Kabupaten Pekalongan. Seminar Nasional Tahunan Ke-V Hasil-Hasil Penelitian Perikanan dan Kelautan, 2016 Semarang. Fakultas Perikanan dan Ilmu Kelautan UNDIP, 658-668

McLennan SM (2001) Relationships between the trace element compo- sition of sedimentary rocks and upper continental crust. Geochem Geophys Geosyst 2

Mirza R, Moeinaddini M, Pourebrahim S, Zahed MA (2019) Contamination, ecological risk and source identification of metals by multivariate analysis in surface sediments of the Khouran Straits, the Persian Gulf. Mar Pollut Bull 145:526-535 
Mohanty RK, Ambast SK, Panigrahi P, Mandal KG(2018) Water quality suitability and water use indices: useful management tools in coastal aquaculture of Litopenaeus vannamei. Aquaculture 485:210-219

Mohapatra A, Rautray TR, Vijayan V, Mohanty RK, Dey SK (2007) Trace elemental characterization of some food crustacean tissue samples by EDXRF technique. Aquaculture 270:552-558

Mok WJ, Senoo S, Itoh T, Tsukamasa Y, Kawasaki K-I, Ando M (2012) Assessment of concentrations of toxic elements in aquaculture food products in Malaysia. Food Chem 133:1326-1332

Muller G (1969) Index of geoaccumulation in sediments of the Rhine River. Geojournal 2:108-118

Nascimento JR, Bidone ED, Rolão-Araripe D, Keunecke KA, Sabadini- Santos E (2016) Trace metal distribution in white shrimp (Litopenaeus schmitti) tissues from a Brazilian coastal area. Environ Earth Sci 75:990

Nowrouzi M, Pourkhabbaz A (2014) Application of geoaccumulation index and enrichment factor for assessing metal contamination in the sediments of Hara Biosphere Reserve, Iran. Chem Speciat Bioavailab 26:99-105

Núñez-Nogueira G, Fernández-Bringas L, Ordiano-Flores A, Gómez- Ponce A, De León-Hill CP, González-Farías F (2012) Accumulation and regulation effects from the metal mixture of $\mathrm{Zn}, \mathrm{Pb}$, and $\mathrm{Cd}$ in the tropical shrimp Penaeus vannamei. Biol Trace Elem Res 150:208-213

NYSDOH (2007) Hopewell precision area contamination: appendix C- NYS DOH. Procedure for evaluating potential health risks for con- taminants of concern. New York State Department of Health, New York

Páez-Osuna F, Ruiz-Fernández C (1995) Trace metals in the Mexican shrimp Penaeus vannamei fromestuarine and marine environments. Environ Pollut 87:243-247

Páez-Osuna F, Tron-Mayen L (1996) Concentration and distribution of heavy metals in tissues of wild and farmed shrimp Penaeus vannamei from the northwest coast of Mexico. Environ Int 22: 443-450

Pandey B, Agrawal M, Singh S (2015) Ecological risk assessment of soil contamination by trace elements around coal mining area. J Soils Sediments 16:159-168

Paul BG, Vogl CR (2013) Organic shrimp aquaculture for sustainable household livelihoods in Bangladesh. Ocean Coast Manag 71:1-12 Pourang N, Dennis JH, Ghourchian H (2004) Tissue distribution and redistribution of trace elements in shrimp species with the emphasis

on the roles of metallothionein. Ecotoxicology 13:519-533 Prapaiwong N, Boyd CE (2014) Trace elements in waters of inland, low-

salinity shrimp ponds in Alabama. Aquac Res 45:327-333

Puspita UR, Siregar AS, Hidayati NV (2011) Kemampuan tumbuhan air sebagai agen fitoremediator logam berat kromium (Cr) yang terdapat pada limbah cair industri batik. Terubuk 39:58-64

Puspita LVJ, Afiati N, Purnomo PW (2018) Water quality appropriate- ness for some allotment in coastal area (case study: Pesantren and Mojo Village, Ulujami, Pemalang). J Maquares 7:110-120

Qian D, Xu C, Chen C, Qin JG, Chen L, Li E (2020) Toxic effect of chronic waterborne copper exposure on growth, immunity, anti-ox- idative capacity and gut microbiota of Pacific white shrimp Litopenaeus vannamei. Fish Shellfish Immun 100:445-455

Qing X, Yutong Z, Shenggao L (2015) Assessment of heavy metal pol- lution and human health risk in urban soils of steel industrial city (Anshan), Liaoning, Northeast China. Ecotoxicol Environ Saf 120: 377-385

Qiu Y-W (2015) Bioaccumulation of heavy metals both in wild and mariculture food chains in Daya Bay, South China. Estuar Coast Shelf Sci 163:7-14

Qiu X, Tian H, Davis DA (2017) Evaluation of a high protein distiller's dried grains product as a protein source in practical diets for Pacific white shrimp Litopenaeus vannamei. Aquaculture480:1-10

Rachmansyah, Mustafa A, Paena M (2010) Characteristics, suitability, and management of land for brackishwater ponds in Pekalongan City, Central Java Province. J Ris Akuakultur 5:505-521

Rahman MS, Saha N, Molla AH (2014) Potential ecological risk assess- ment of heavy metal contamination in sediment and water body around Dhaka export processing zone, Bangladesh. Environ Earth Sci 71:2293-2308

Ranjan P, Ramanathan AL, Kumar A, Singhal RK, Datta D, Venkatesh M(2018)Tracemetal distribution, assessmentandenrichmentinthe surface sediments of Sundarban mangrove ecosystem in India and Bangladesh. Mar Pollut Bull 127:541-547

Rashidi HR, Sulaiman NMN, Hashim NA (2012) Batikindustry synthet- ic wastewater treatment using nanofiltration membrane. Procedia Engi 44:2010-2012

Rink L, Kirchner H (2000) Zinc-altered immune function and cytokine production. J Nutr 130:1407S-1411S

Ruelas-InzunzaJ,Páez-OsunaF(2004)Distributionand concentration of trace metals in tissues of three penaeid shrimp species from Altata- Ensenada del Pabellón Lagoon (S.E. Gulf of California). Bull Environ Contam Toxicol 72:452-459

Rukayah RS, Wibowo AA, Wahyuningrum SH (2015) Public participa- tion in branding road corridor as shopping window or batik industry at Pekalongan. Procedia Soc Behav Sci 168:76-86

Santos EE, Lauria DC, Porto Da Silveira, CL (2004) Assessment of daily intake of trace elements due to consumption of foodstuffs by adult inhabitants of Rio de Janeiro City. Sci Total Environ 327:69-79

Sarkar T, Alam MM, Parvin N, Fardous Z, Chowdhury AZ, Hossain S, Haque ME, Biswas N (2016) Assessment of heavy metals contam- ination and human health risk in shrimp collected from different farms and rivers at Khulna-Satkhira region, Bangladesh. Toxicol Rep 3:346-350

Satapathy DR, Panda CR (2015) Spatio-temporal distribution of major and trace metals in estuarine sediments of Dhamra, Bay of Bengal, India-its environmental significance. Environ Monit Assess 187: 4133

Sawitri R, Karlina E(2006) Riverine quality of wetlands in Comal River, Pemalang and Kedung Coet river, Indramayu. Jurnal Penelitian Hutan Dan Konservasi Alam 3:185-195

Setiyono A, Gustaman RA (2017) Pengendalian kromium (Cr) yang terdapat di limbah batik dengan metode fitoremediasi. Unnes J Public Health 6:155-160

Sfakianakis DG, Renieri E, Kentouri M, Tsatsakis AM (2015) Effect of heavy metals on fish larvae deformities: a review. Environ Res 137: 246-255

Soegianto A, Irawan B, Usman N (2013) Effects of sublethal copper concentrations on gills of white shrimp (Litopenaeus vannamei, Boone 1931). Bull Environ Contam Toxicol 91:630-634

Soto-Jiménez MF, Arellano-Fiore C, Rocha-Velarde R, Jara-Marini ME, Ruelas-Inzunza J, Páez-Osuna F (2011) Trophic transfer of lead through a model marine four-level food chain: Tetraselmis suecica, Artemia franciscana, Litopenaeus vannamei, and Haemulon scudderi. Arch Environ 
Contam Toxicol 61:280-291

Srichandan S, Panigrahy RC, Baliarsingh SK, Rao BS, Pati P, Sahu BK, Sahu KC (2016)Distribution of trace metals in surface seawater and zooplankton of the Bay of Bengal, off Rushikulya estuary, East Coast of India. Mar Pollut Bull 111:468-475

Suantika G, Situmorang ML, Kurniawan JB, Pratiwi SA, AditiawatiP, Astuti DI, Azizah FFN, Djohan YA, Zuhri U, Simatupang TM (2018) Development of a zero water discharge (ZWD) - recirculating aquaculture system (RAS) hybrid system for super intensive white shrimp (Litopenaeus vannamei) culture under low salinity conditions and its industrial trial in commercial shrimp ur- ban farming in Gresik, East Java, Indonesia. Aquac Eng 82:12-24

Syakti AD, Demelas C, Hidayati NV, Rakasiwi G, Vassalo L, Kumar N, Prudent P, Doumenq P (2015) Heavy metal concentrations in natural and human-impacted sediments of Segara Anakan Lagoon, Indonesia. Environ Monit Assess 187:4079

Takarina ND, Pin TG (2017) Bioconcentration factor (BCF) and translo- cation factor (TF) of heavy metals in mangrove trees of Blanakan fish farm. Makara J Sci 21:77-81

Taylor SR (1964) Abundance of chemical elements in the continental crust: a new table. Geochim Cosmochim Acta 28:1273-1285

Turekian KK, Wedepohl KH(1961)Distribution of the elements in some major units of the earth's crust. Geol Soc Am Bull 72:175-192

USEPA (1989) Risk assessment guidance for superfund. Volume I: hu- man health evaluation manual (part A). EPA/540/1-89/002

USEPA (2002) A review of the reference dose and reference concentra- tion processes. V. U.S. Environmental Protection Agency, Washington USEPA (2018) USEPA regional screening level (RSL) summary table: November 2018. USEPA (United States Environmental Protection Agency)last update: November, 2018

Wahyuningrat, Haryanto T, Rosyadi S (2018) Practices of illegal fishing in Pemalang region: a policy analysis. In: 2nd scientific communi- cation in fisheries and marine sciences (SCiFiMaS 2018). EDP Sciences, Purwokerto

Walpole SC, Prieto-Merino D, Edwards P, Cleland J, Stevens G, Roberts I (2012) The weight of nations: an estimation of adult human bio- mass. BMC Public Health 12:439

Wang SL, Xu XR, Sun YX, Liu JL, Li HB (2013) Heavy metal pollution in coastal areas of South China: a review. Mar Pollut Bull 76:7-15 Wang Z, Dong X, Zhou S, Yan C, Yan Y, Chi Q (2014) Contamination assessments of surface water in coastal lagoon(Maluan Bay, China) incorporating biomarker responses and bioaccumulation in hepato- pancreas of exposed shrimp (Litopenaeus vannamei)—an integra-

tive approach. Environ Sci Pollut Res 21:205-219

Watanabe T, Kiron V, Satoh S (1997) Trace minerals in fish nutrition.

Aquaculture 151:185-207

WHO (2004) Manganese and its compounds: environmental aspects.

World Health Organization, Geneva

Wu JP, Chen H-C (2004) Effects of cadmium and zinc on oxygen con- sumption, ammonium excretion, and osmoregulation of white shrimp (Litopenaeus vannamei). Chemosphere 57:1591-1598

Wu JP, Chen HC (2005) Metallothionein induction and heavy metal accumulation in white shrimp Litopenaeus vannamei exposed to cadmium and zinc. Comp Biochem Physiol C Toxicol Pharmacol 140:383-394

Wu X-Y, Yang Y-F (2011) Heavy metal ( $\mathrm{Pb}, \mathrm{Co}, \mathrm{Cd}, \mathrm{Cr}, \mathrm{Cu}, \mathrm{Fe}, \mathrm{Mn}$ and $\mathrm{Zn}$ ) concentrations in harvest-size white shrimp Litopenaeus vannamei tissues from aquaculture and wild source. J Food Compos Anal 24:62-65

Wu H, Liu J, Bi X, Lin G, Feng CC, Li Z, Qi F, Zheng T, Xie L (2017) Trace metals in sediments and benthic animals from aquaculture ponds near a mangrove wetland in southern China. Mar Pollut Bull 117:486-491

Xavier DA, Schettini CA, Franca EJ, Figueira RC, Barcellos RL (2017) Determination of geochemical background values on a tropical es- tuarine system in a densely urban area. Case study: Capibaribe es- tuary, northeastern Brazil. Mar Pollut Bull 123:381-386

Yabanli M, Alparslan Y (2015) Potential health hazard assessment in terms of some heavy metals determined in demersal fishes caught in eastern Aegean Sea. Bull Environ Contam Toxicol 95:494-498

Yan N, Liu W, Xie H, Gao L, Han Y, Wang M, Li H (2016) Distribution and assessment of heavy metals in the surface sediment of Yellow River, China. J Environ Sci 39:45-51

Yang J, Cui Z, Dada OA, Yang Y, Yu H, Xu Y, Lin Z, Chen Y, Tang X (2018)Distribution andenrichment of tracemetals in surface marine sediments collected by the manned submersible Jiaolong in the Yap Trench, northwest Pacific Ocean. Mar Pollut Bull 135:1035-1041

Yavar Ashayeri N, Keshavarzi B (2019) Geochemical characteristics, partitioning, quantitative source apportionment, and ecological and health risk of heavy metals in sediments and water: a case study in Shadegan wetland, Iran. Mar Pollut Bull 149:110495

Ye Z, Li Q, Liu J, Luo S, Zhou Q, Bi C, Ma S, Chen Y, Chen H, Li L, Ge X (2017) Investigation of submicron aerosol characteristics in Changzhou, China: composition, source, and comparison with co- collected PM2.5. Chemosphere 183:176-185

Yuan Y, Jin M, Xiong J, Zhou Q (2019) Effects of dietary dos- age forms of copper supplementation on growth, antioxidant capacity, innate immunity enzyme activities and gene expres- sions for juvenile Litopenaeus vannamei. Fish Shellfish Immunol 84:1059-1067

Yulianto B, Oetari PS, Februhardi S, Putranto WC, Soegianto A (2019) Heavy metals (Cd, Pb, Cu, Zn) concentrations in edible bivalves harvested from northern coast of Central Java, Indonesia. International Conference on Science and Technology for Environmental Protection. Surabaya: IOP Publishing Ltd.

Zhang J, Liu CL (2002) Riverine composition and estuarine geo- chemistry of particulate metals in China-weathering fea- tures, anthropogenic impact and chemical fluxes. Estuar Coast Shelf Sci 54:1051-1070

Zhang Y, Lu X, Wang N, Xin M, Geng S, Jia J, Meng QJES, Research P (2016) Heavy metals in aquatic organisms of different trophic levels 
and their potential human health risk in Bohai Bay, China. Environ Sci Pollut R 23:17801-17810

Zhang Y, Chu C, Li T, Xu S, Liu L, Ju M (2017) A water quality management strategy for regionally protected water through health risk assessment and spatial distribution of heavy metal pollution in 3 marine reserves. Sci Total Environ 599-600:721-731

Zhang W, Zhang X, Tian Y, Zhu Y, Tong Y, Li Y, Wang X (2018) Risk assessment of total mercury and methylmercury in aquatic products from offshore farms in China. J Hazard Mater 354:198-205

Zhao R, Yan S, Liu M, Wang B, Hu D, Guo D, Wang J, Xu W, Fan C (2016) Seafood consumption among Chinese coastal residents and health risk assessment of heavy metals in seafood. Environ Sci Pollut Res Int 23:16834-16844

Zhong S, Geng H, Zhang F, Liu Z, Wang T, Song B (2015) Risk assess- ment and prediction of heavy metal pollution in groundwater and river sediment: a case study of a typical agricultural irrigation area in Northeast China. Int J Anal Chem 2015:921539 